$$
\begin{aligned}
& \text { مرورى بر جايكاه يخوهشى برند در آزانسهاى مسافرتى جهان }
\end{aligned}
$$

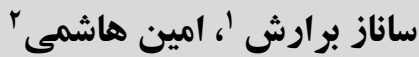

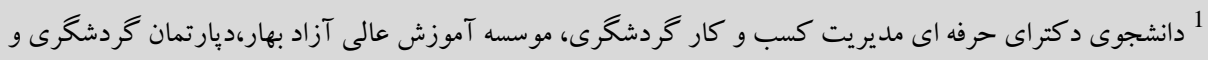

$$
\begin{aligned}
& \text { هتلدارى،تهران،ايران } \\
& \text { 'دانشجوى د كتراى تخصصى مديريت گرايش سياست گذارى علم وفناورى - دانشگاه علم وصنعت ايران، تهر ان، ايران }
\end{aligned}
$$

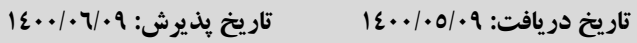

\title{
A review of Brand in Travel Agency through international studies
}

\section{Sanaz Bararesh ', Amin Hashemi ${ }^{2}$}

1 Professional PhD Student in Tourism Business Management, Bahar Free Higher Education Institute, Department of Tourism and Hospitality, Tehran, Iran

PhD student in Science and Technology Policy Orientation Management - Iran University of Science and Technology, Tehran, Iran

Received: (30/07/2021) Accepted: (29/08/2021)

\section{شناسه يكتا}

\section{Abstract}

In today's highly competitive world of the tourism industry, brands, which are the intangible assets of companies, play a key role in differentiating actors in this field. Today, these are successful brands that can survive in the competition, achieve long-term financial stability for brand owners, and ensure customer trust. Studies show that not much research has been done in this area to express the need for brands and branding in travel agencies, which are one of the most important service providers in the travel service supply chain.

Therefore, this research seeks to contribute to the extant knowledge of brand by systematically reviewing the related literature, providing detailed analysis and discussions as well as comprehensive categorization for the brand concept and its elements in travel agencies while suggesting direction for future research.

In this study, all credible articles in the Scopus database in this field (32 articles) from 2003 to 2020 have been identified, reviewed, and while summarizing and classifying existing research concepts, quantitative and qualitative analyzes of these researches has been provided. This research may aid researchers, brand managers and business owners of tourism services in adopting the appropriate strategy for brand choice as well as advancing related fields of study

Keywords

Brand, Tourism Service, Travel Agency, Literature review

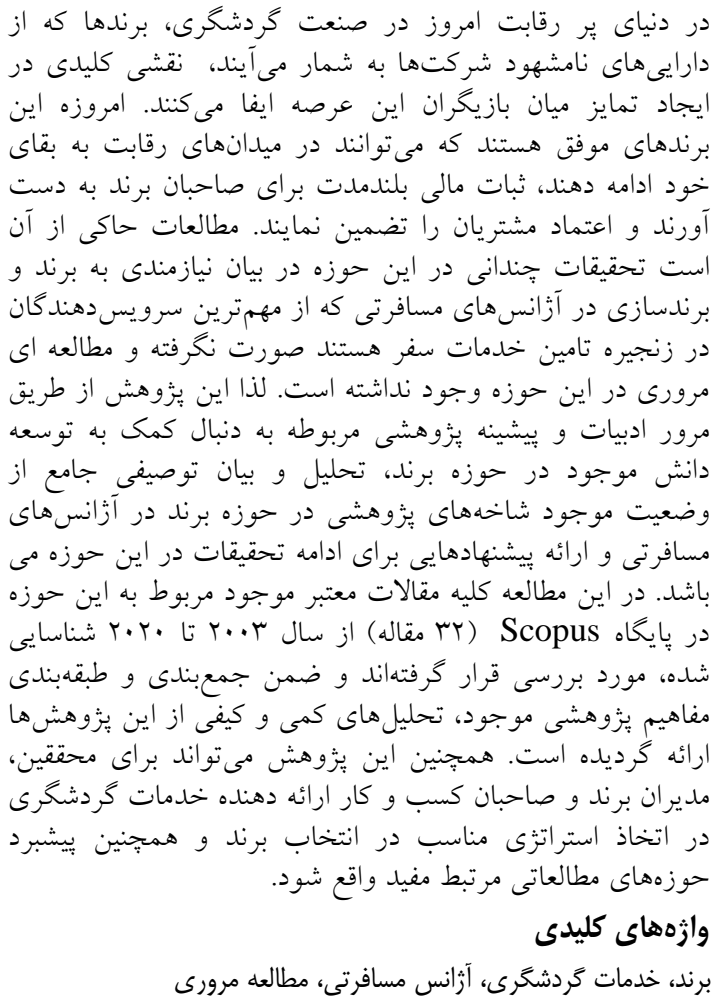


مديريت برند انجام شده است. اين در حالى است كه مطالعات

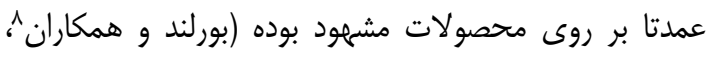

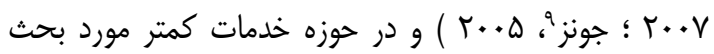

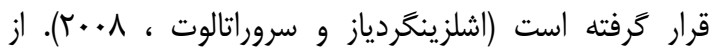

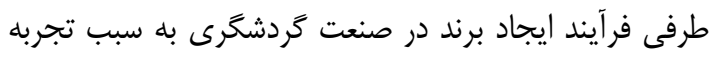

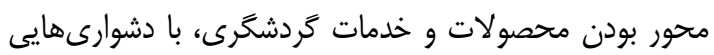
همراه بوده و جندان مشابه با برندسازى در ساير صنايع نيست

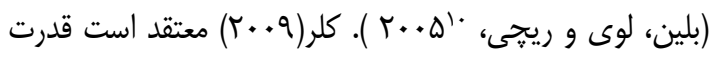

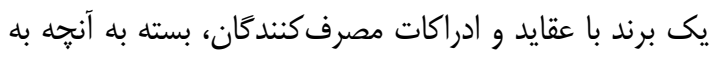

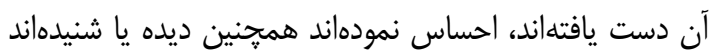

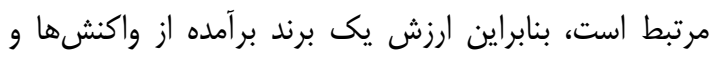

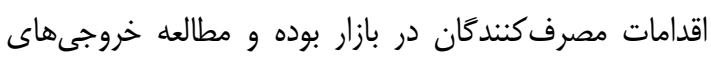

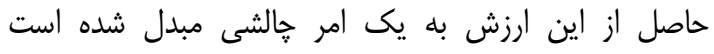

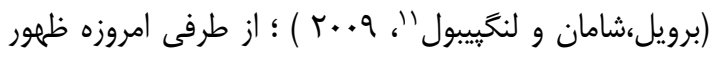

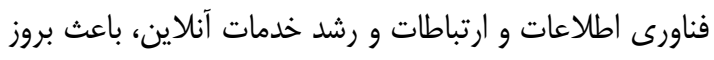

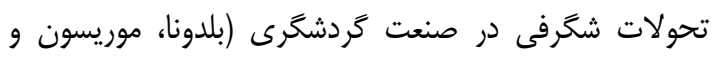

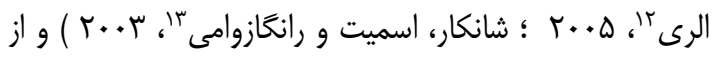

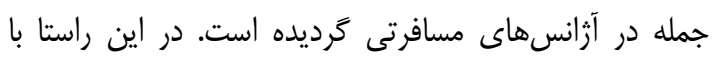

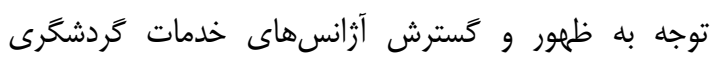

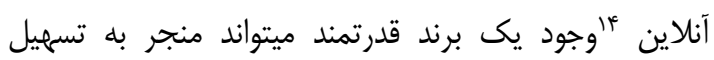

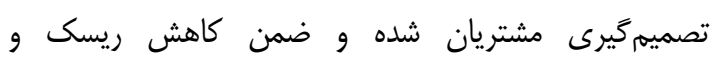

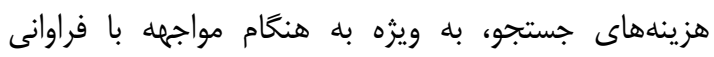

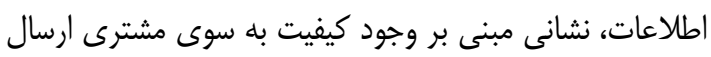

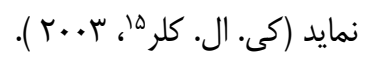

كسترش فناورىهاى ديجيتال، آرَانسهاى خداى خدمات مسافرتى

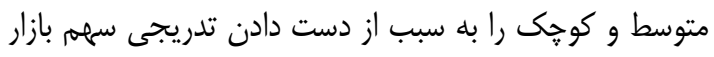
فروش با مشكلاتى نيز مواجه نموده است. در اين إنى راستا

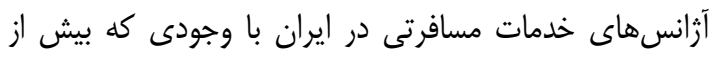

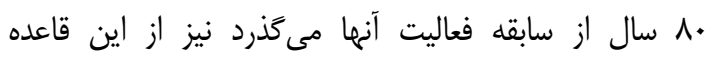

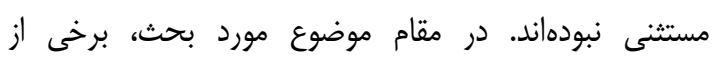

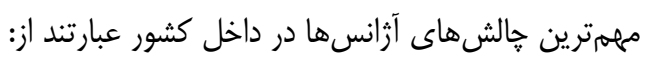

\footnotetext{
${ }^{8}$ Beverland et al.

${ }^{9}$ Jones

${ }^{10}$ Blain, Levy, \& Ritchie

${ }^{11}$ Broyles, Schumann, \& Leingpibul

${ }^{12}$ Beldona, Morrison, \& O'Leary

${ }^{13}$ Shankar, Smith, \& Rangaswamy

${ }^{14}$ Online Travel Agency (OTA)

${ }^{15}$ K. L. Keller
}

مقدمه

بر اساس كزارش شوراى جهانى كَردشَّى و سفر در سال

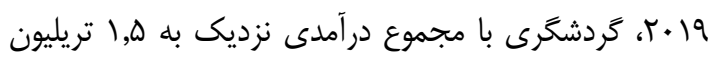

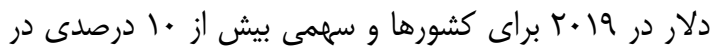

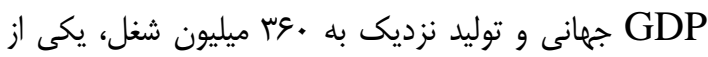

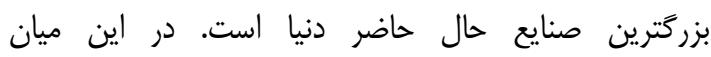

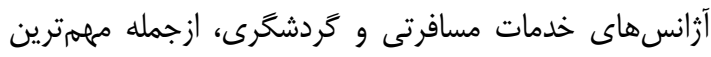

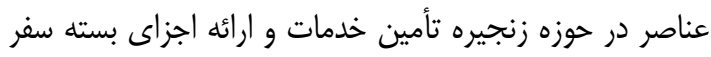

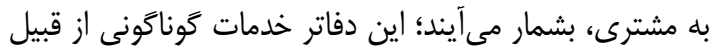
سرويسهاى حملونقل، بستههاى سفر، بيمه، اقامتخاه و و همجنين خدمات مشاورهاى به مشتريان ارائه مىنمايند كه به به

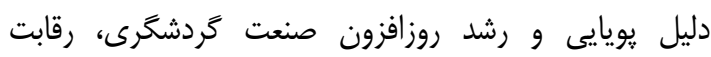
جشمَيرى در بازار آزانسهاى خدمات مسافرتى براى ارائه

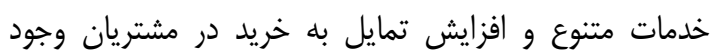

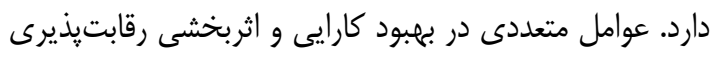

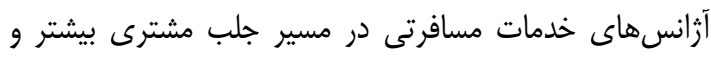

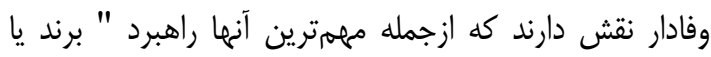

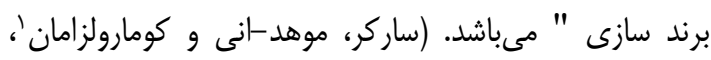
مطالعات نشان مىدهد، برند يا نشان يك شركت از دارايى

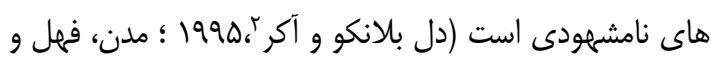

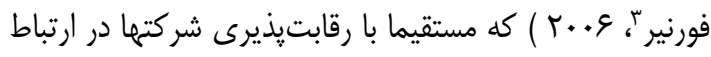

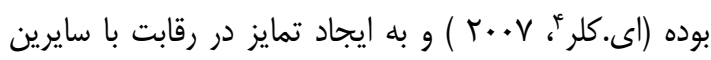

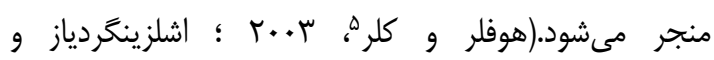

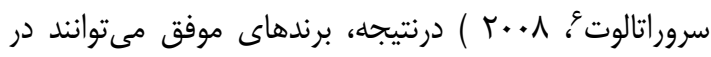

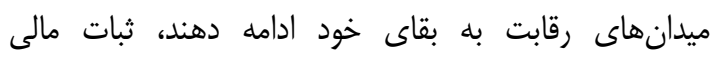

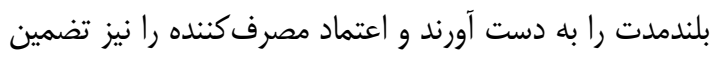

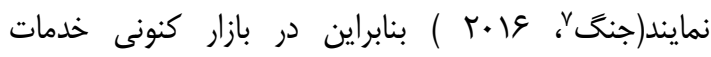

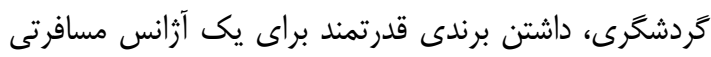

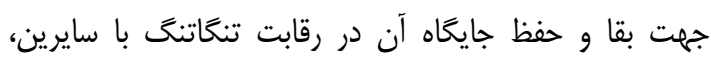
مى تواند راهكارى اثربخش بشمار آيد.

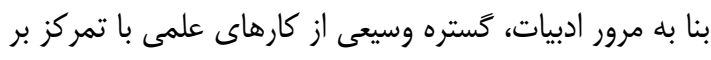

I Sarker, Mohd-Any, \& Kamarulzaman $r$ del Blanco \& Aaker

${ }^{3}$ Madden, Fehle, \& Fournier

${ }^{4}$ E. Keller

${ }^{5}$ Hoeffler \& Keller

${ }^{6}$ Schlesinger Díaz \& Cervera Taulet

${ }^{7}$ Jeng 


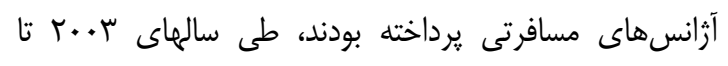

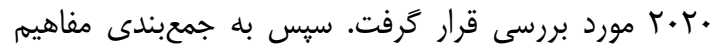
مرتبط با برند و همجنين تاثيرات آن بر خدمات ارائه شده برد

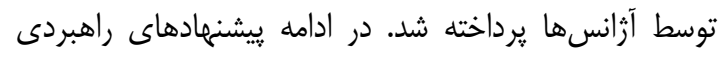
براى كمك به محققين و مديران برند در اين حوزه ارائه شده

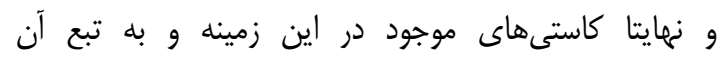

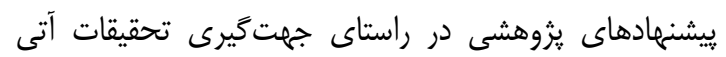

$$
\text { بيان گرديده است. }
$$

\section{شناسايى مفاهيم مربوط بـ حوزه برن برند در} آزانس هاى مسافر تى

\section{روش شناسى}

مطالعه حال حاضر در قالب مقاله مرورى تدوين شده و به به

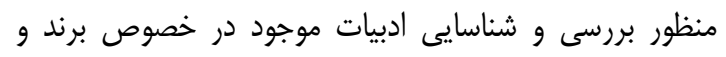

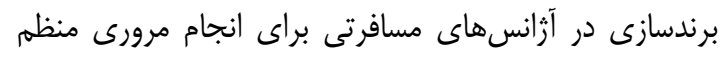

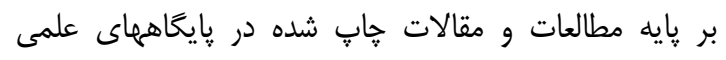

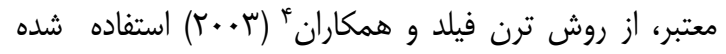

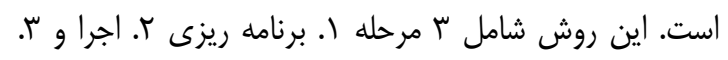
گزارشدهى و انتشار مطلب مرورى است.

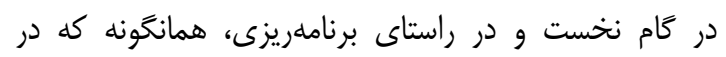

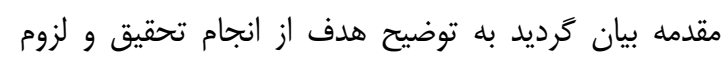

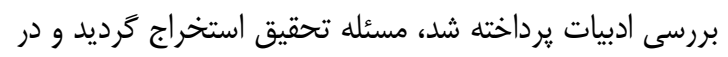

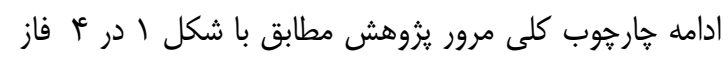

\section{شكل I. جارجوب كلى مرور ״يزوهش}

$$
\text { تلدوين شد. }
$$

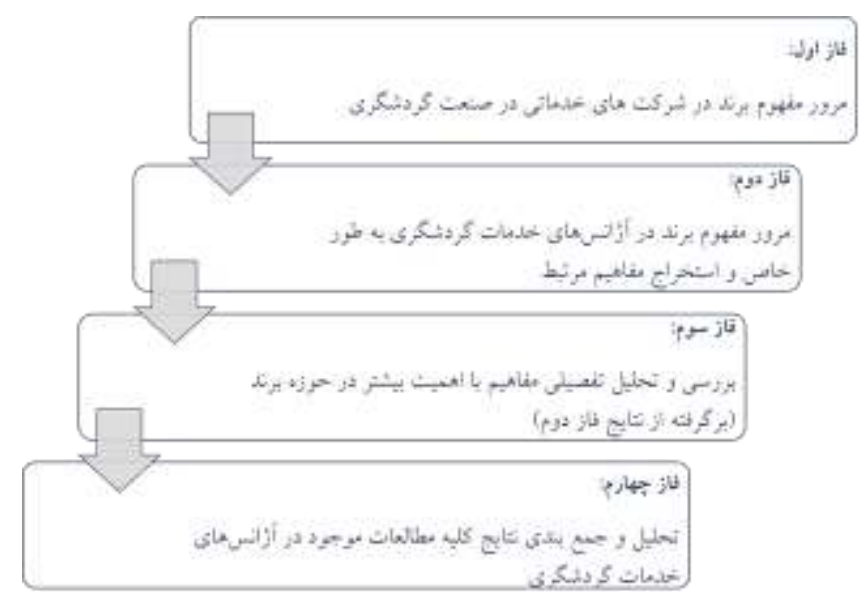

$$
\text { طرح از : س. برارش و ا. هاشمى }
$$

در كام دوم و در مرحله اجرا، ابتدا به منظور دستيابى به

\footnotetext{
${ }^{4}$ Tranfield et al.
}

كم توجهى به اجزا و دارايىهاى برند از منظر

علمى، فنى، اجرايى و مالى و عدم تمركز و و سرمايهگذارى اجى

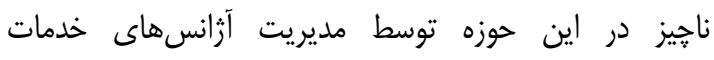
مسافرتى؛

كمتوجهى به خلاقيت و نوآورى در ارائه خدمات متنوع ، بروز و ويزه متأثر از نياز مشترى و بازار براى ارئه ائه

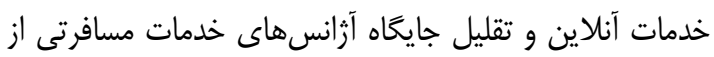

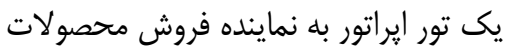
تصوير ذهنى نادرست از محتوا، نام و نشانه برند

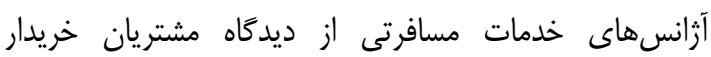

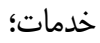
ادراك كيفيت نامناسب در دريافت خدمات از آزانسهاى خدمات مسافرتى از ديدگاه مشتريان؛ دامنه ارتباطات ضعيف و گَسسته به لحاظ مات اعتماد به ديه خدمات ارائهشده از منظر محتوا، قيمت و كيفيت و تبعاط نارضايتى يا رضايتمندى محدود؛

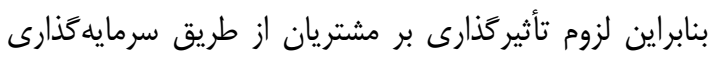
بر موضوع برند و مديريت آن توسط مديران و صاحبان

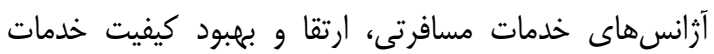

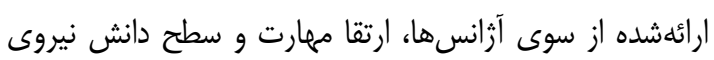
شاغل و افزايش آَاهى و شناخت آزانس از سوى آنس مشتريان آرنان بهعنوان شاخصهايى براى افزايش رقابتيذيرى هه در سطح

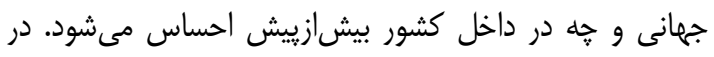

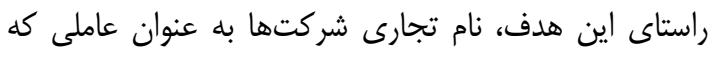

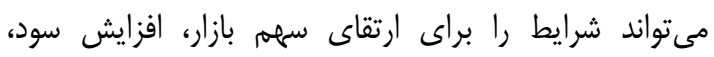

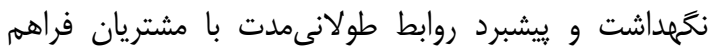

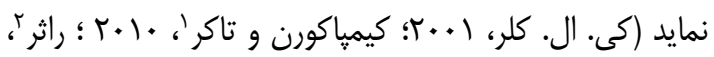

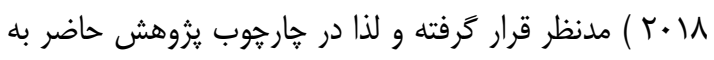

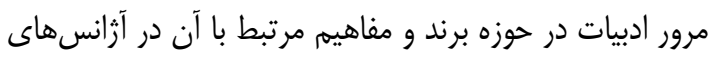

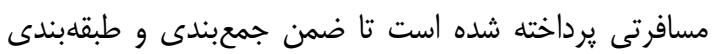

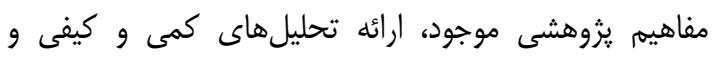

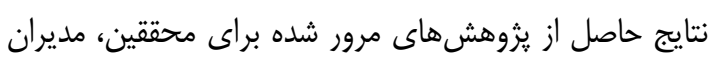

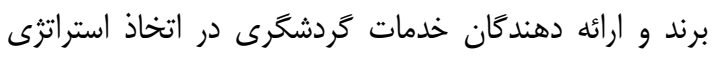

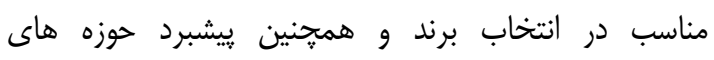
مطالعاتى مرتبط مفيد واقع شود. براى دستيابى به اهداف حاصل از يزوهش ابتدا مقالات معتبر

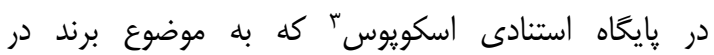

\footnotetext{
${ }^{1}$ Kimpakorn \& Tocquer 
شكل r. ابر لغات حاصل از جِكيده يزوهش هاى مرتبط با مفهوم برند در صنايع خدمات تَردشكَى تا سال $r+r+$

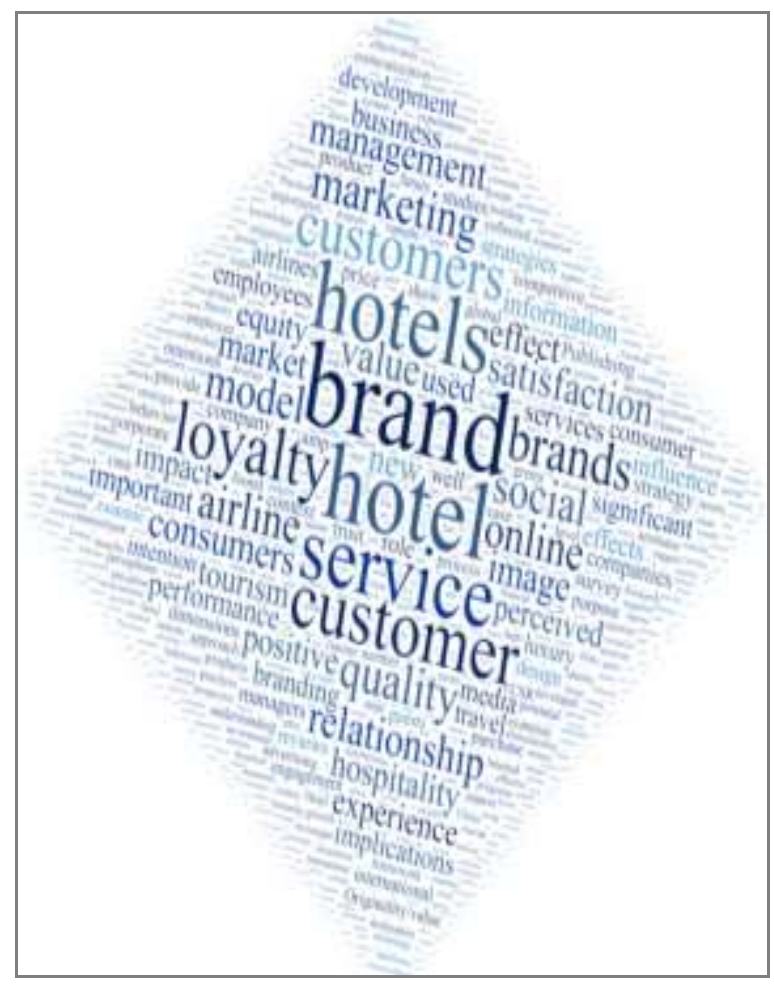

طرح از : س. برارش و ا. هاشمى

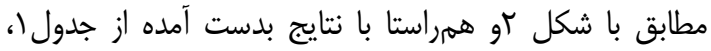

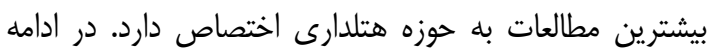

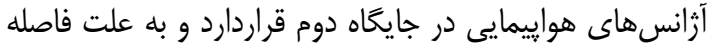

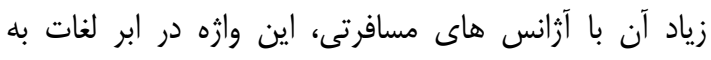
وضوح مشاهده نمى شود. همجنين در بين مفاهيه، "خدماته

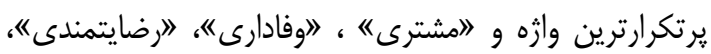

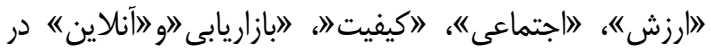

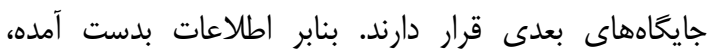

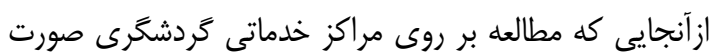

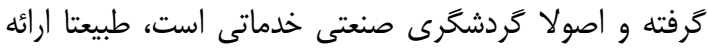

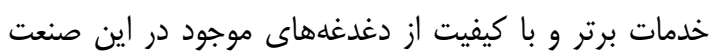
بوده كه با توجه به نتايج بدست آمده اين موضوع در در بحث

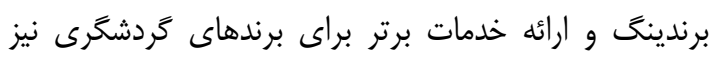

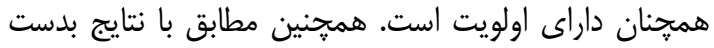

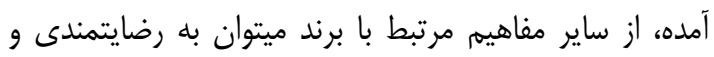
وفادارى و نقش اين مفاهيم بر روى مشتريان، مصرفكنيند إندان و همجنين كارمندان مراكز صاحب برند اشاره نمود كه مطابق

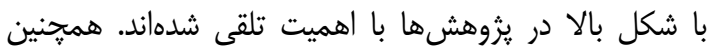

نكَرشى كلى و تسلط بر حوزه مورد بررسى، به جستجوى

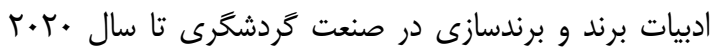

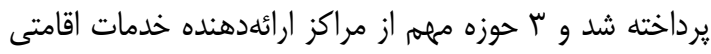
و سفر در صنعت كردشخَى شامل هتلدارى، آزانسهاى

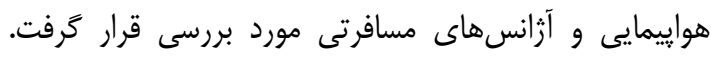
بدين منظور در بايكاه استنادى اسكويوس بهائ جستجوى

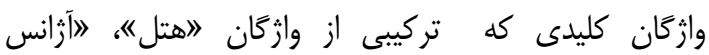

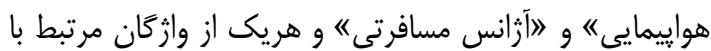
برند و برندينگ به شرح جدول إيرداخته شد.

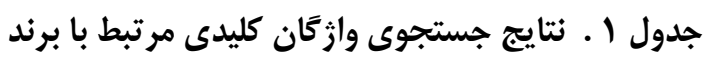

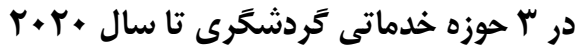

\begin{tabular}{|c|c|c|c|}
\hline 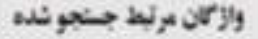 & Trasel Agracy & Airline & Hetel \\
\hline Brad Equiry & 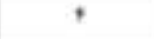 & $*$ & 4 \\
\hline Senvioe Brasting & $\pi$ & $\pi$ & vi \\
\hline $\begin{array}{c}\text { Caibomer Cosiumer. Baned } \\
\text { Brand Equity }\end{array}$ & $*$ & $\mathrm{~A}$ & $\pi$ \\
\hline Aradiag & $\mathbf{Y}$ & $v_{2}$ & $m$ \\
\hline Brand & $w$ & $F \cdot Y$ & $1 .+1$ \\
\hline حس ب & 11. & oft & 1464 \\
\hline
\end{tabular}

منبع: جمع بندى نغارندكان از ادبيات موجود

همان گونه كه از نتايج برمىآيد، بيشترين مطالعات جهانى در

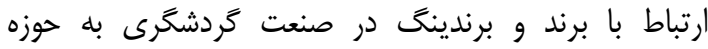

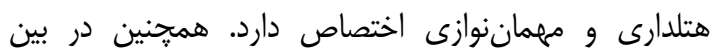

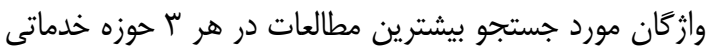

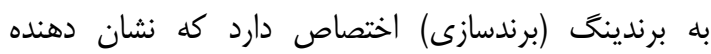
اهميت بالاى اين مفهوم به لحاظ مطالعاتى است. در ادامه به إنه

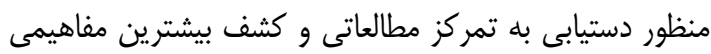

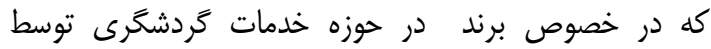

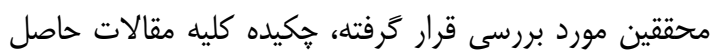

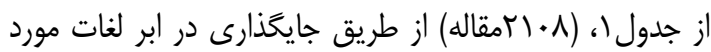

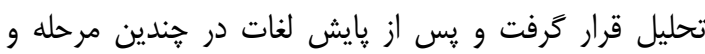

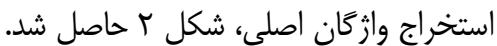


كلى استخراج شد كه نتايج حاصل از اين جستجو يس از ماز

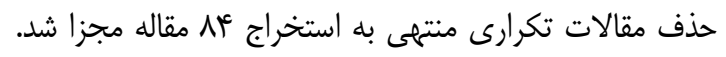
در ادامه براى حصول اطمينان از اين كه مقالات بدست آدئ آمده

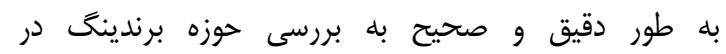

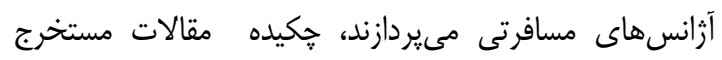

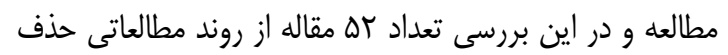

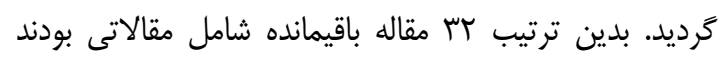

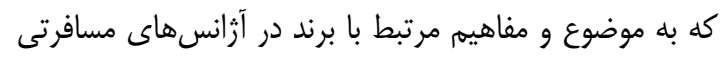

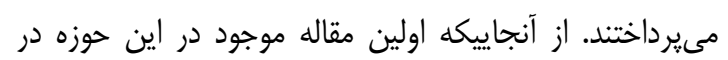

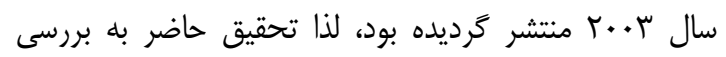

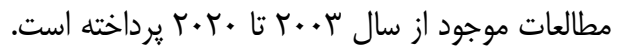

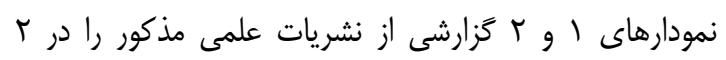
دستهبندى مجزا شامل انتشاراتى كه اين مقالات ات رات رات نمايه

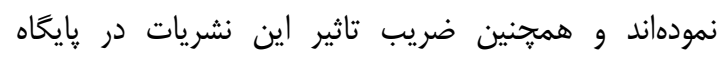
Scopus نمودار 1. آمار تعداد مجلات علمى نمايه شده در بايكاه اطلاعاتى انتشارات

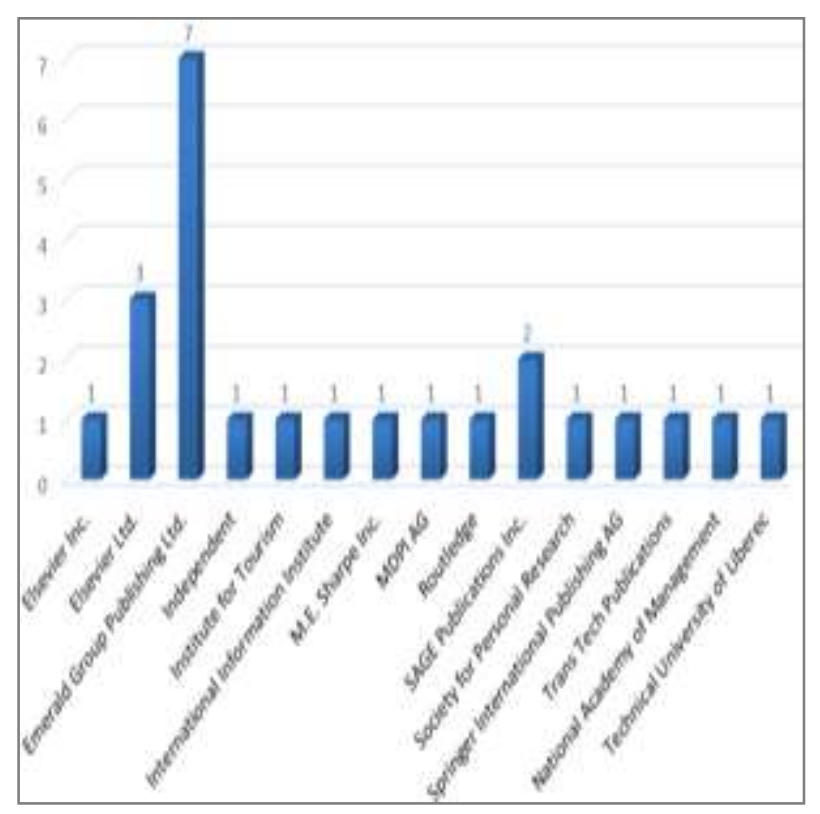

منبع: تحليل نغارندكان
ازازنجايى كه برند از مفاهيم مرتبط با بازاريابى است لذا موضوع

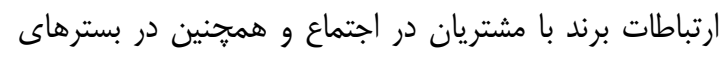

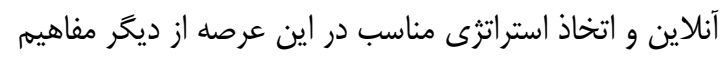

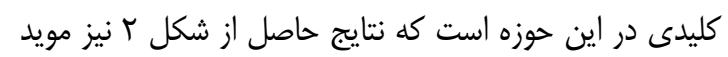
همين مطلب است.

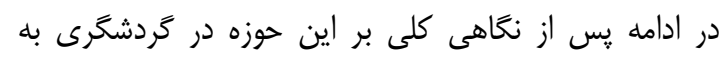

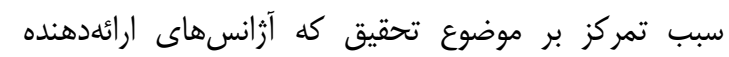

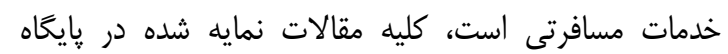

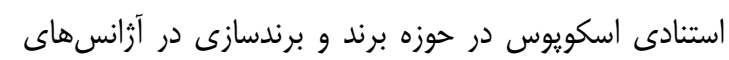

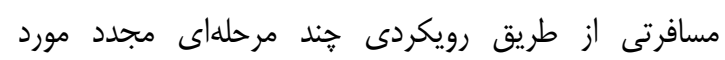

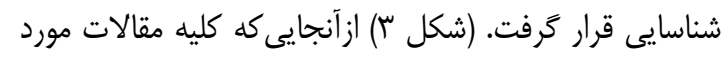

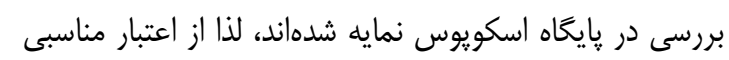

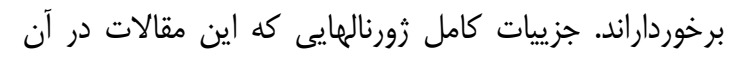

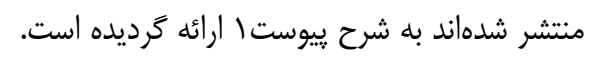

شكل س. فرآيند جستجوى سيستماتيك در استخراج

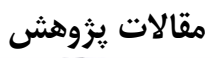

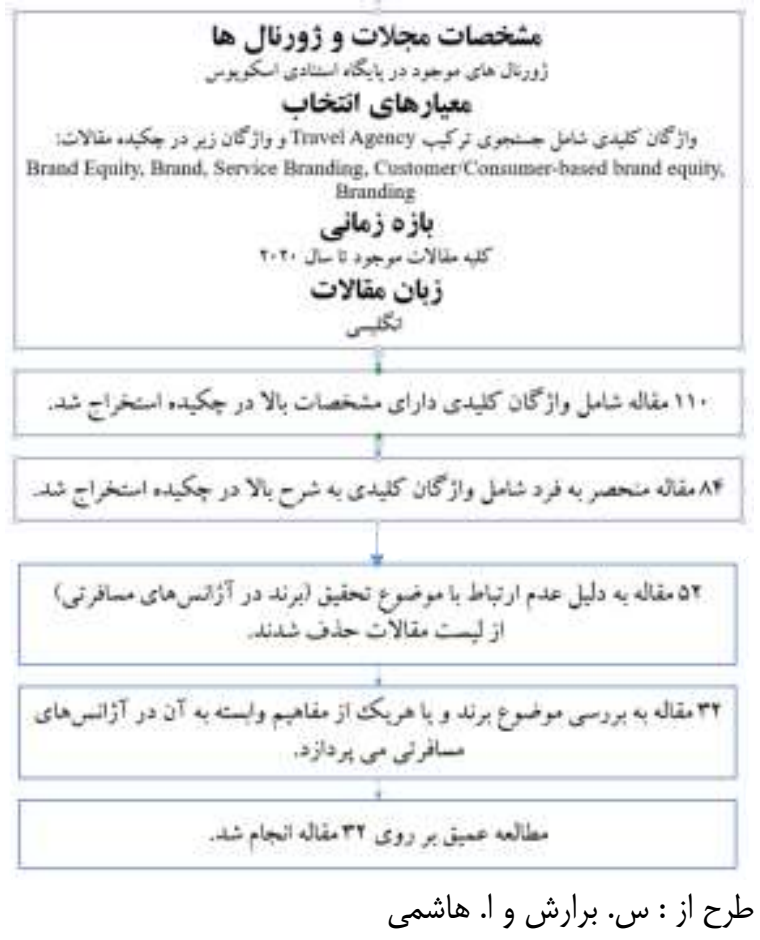

در فرآيند جستجو در مقالات، اين بار تركيبى از كلمات كليدى

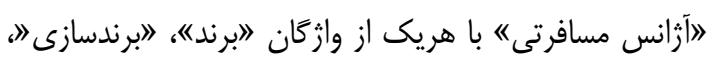

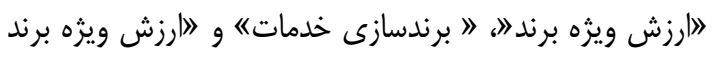

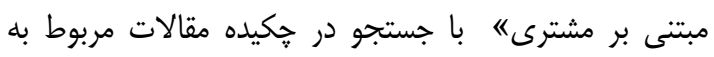

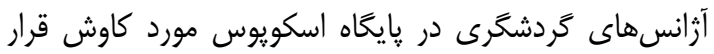

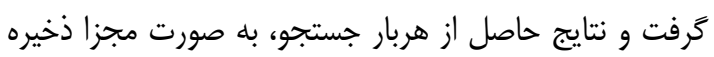

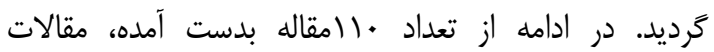

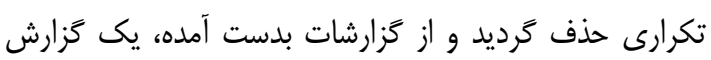


كه به بررسى نقش برند به به عنوان يكى از شاخصههاى

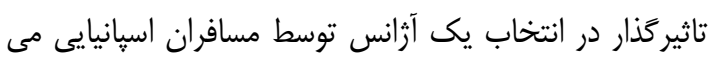

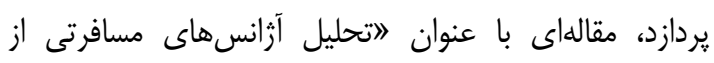
ديدكاه مسافران اوقات فراغته است كه توسط كيل و سليس إنس

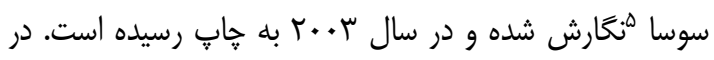
انجام اين تحقيق كه با هدف مطالعه در مورد انكَيزه مشتريان

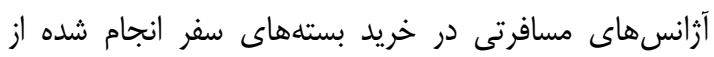

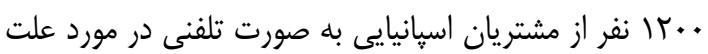

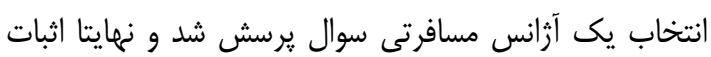

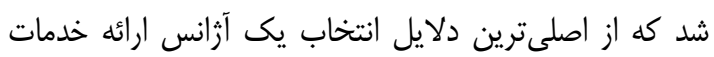

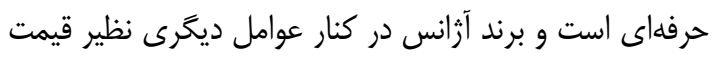

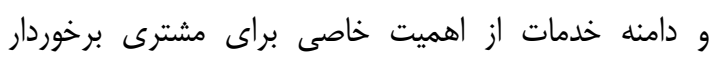

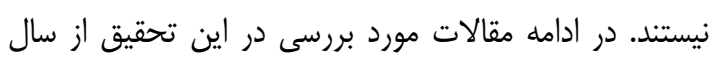

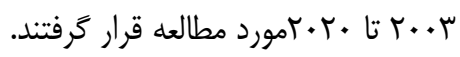

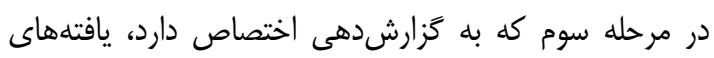

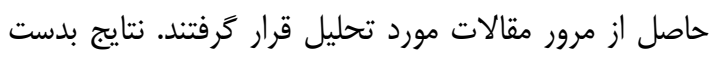

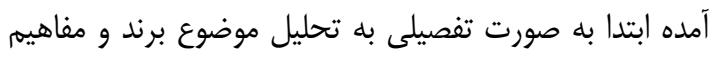

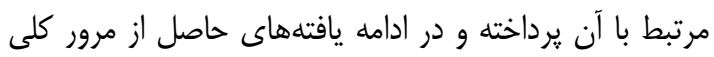

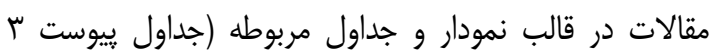

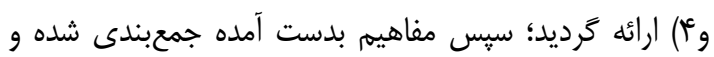

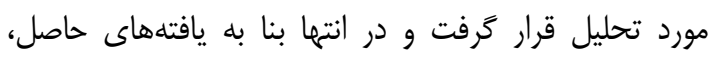
يشينهاداتى براى تحقيقات آتى مطرح گَرديد.

\section{مرورى بر مفهوم برند در آزانسهاى مسافرتى در} جهان تعاريف مختلفى براى برند ارائه كرديده است. كميته (انجمن)

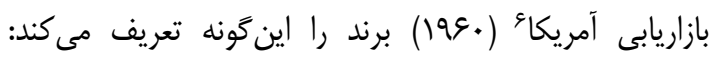

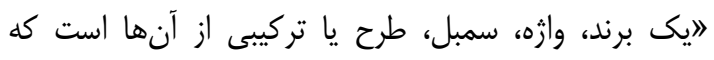

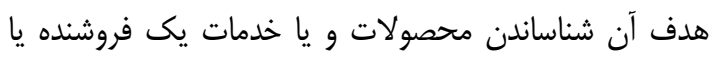

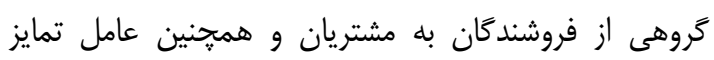

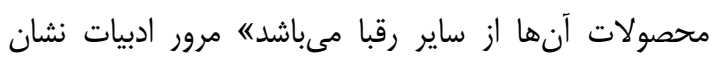

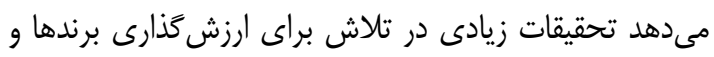

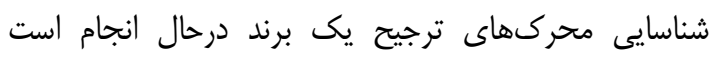

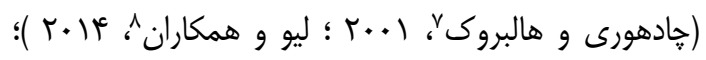

\footnotetext{
${ }^{5}$ Gil \& Celis Sosa

${ }^{6}$ American Merketing Association

${ }^{7}$ American Merketing Association

${ }^{8}$ Liu et al.
}

شده دريايكاه Scopus در سال 19 +

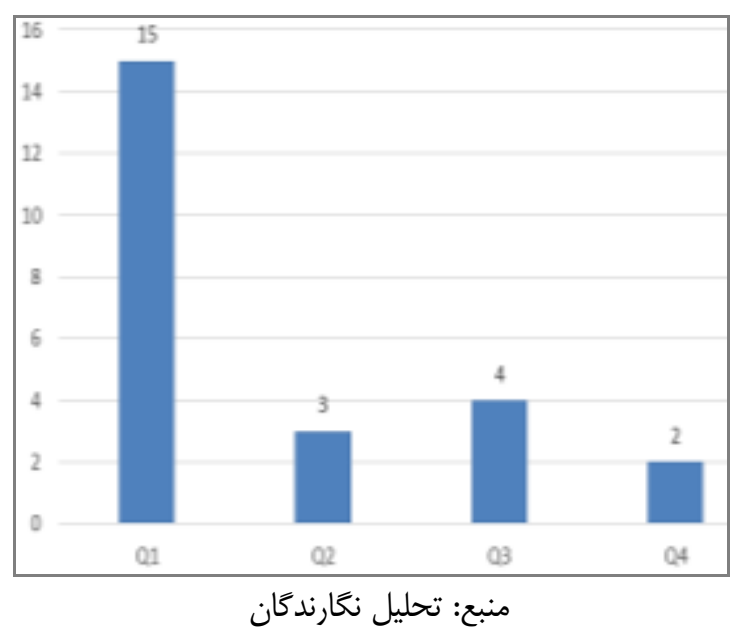

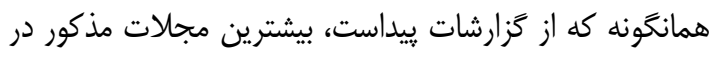

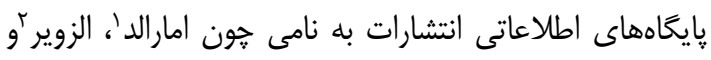

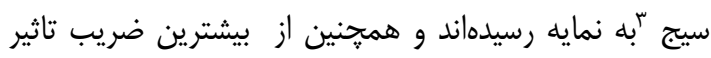

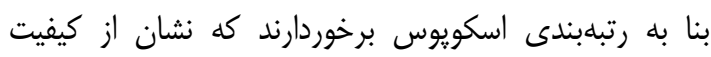

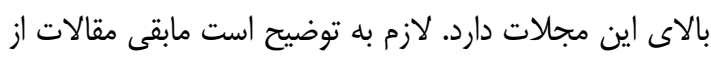

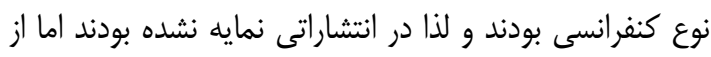

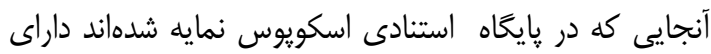
اعتبار كافى مىباشند. همجنين كزارش بررسى امتياز انتساب مقالات به مراكز علمى

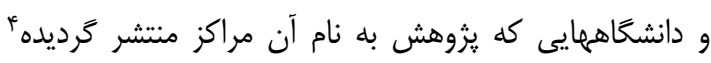

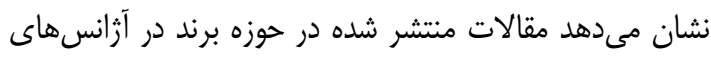

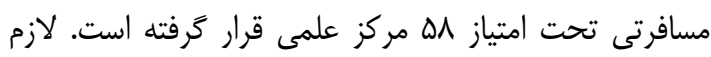

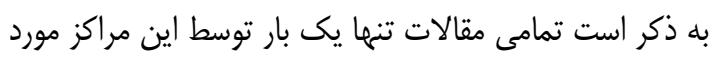

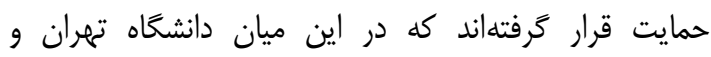

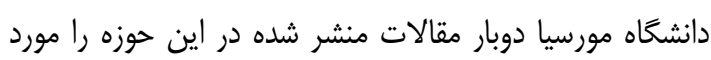

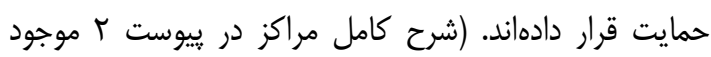

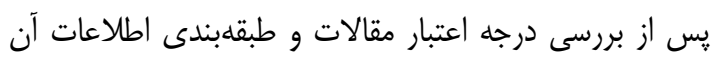

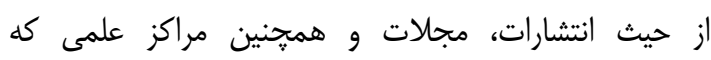

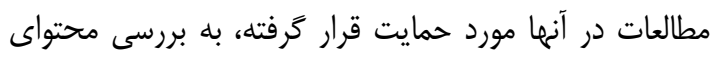

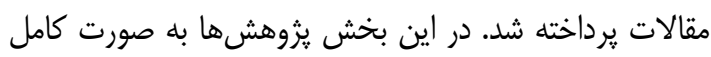
مورد مطالعه قرارگرفت. مطابق با مرور ادبيات، اولين مقالهاى بردي

\footnotetext{
${ }^{1}$ Emerald

${ }^{2}$ Elsevier

${ }^{3}$ Sage

${ }^{4}$ Affiliation
} 


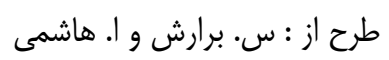

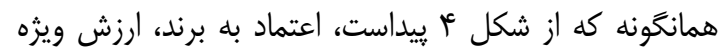

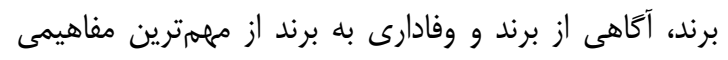

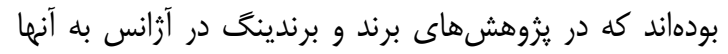

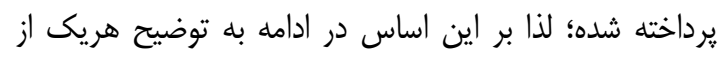

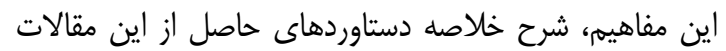

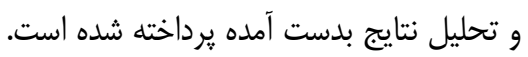

جدول r.جريان مفاهيم ير تكرار يزوهش حول ئردائ موضوع

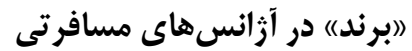

\begin{tabular}{|c|c|c|}
\hline ets & 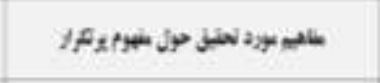 & 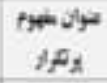 \\
\hline 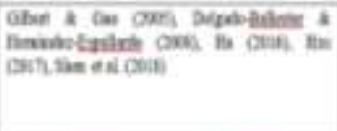 & 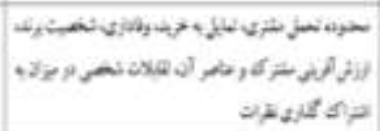 & 4y+st \\
\hline 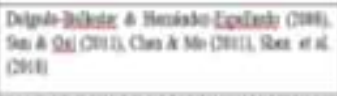 & 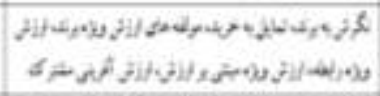 & $4 y+3$ iat \\
\hline 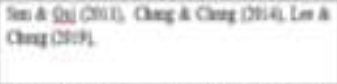 & 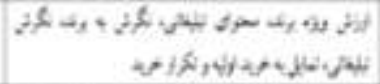 & 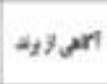 \\
\hline 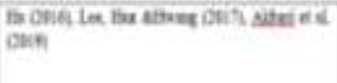 & 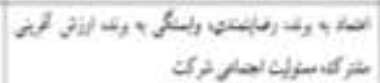 & Aytudthen \\
\hline
\end{tabular}

منبع: تحليل نغارندكان از ادبيات موجود

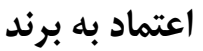

معناى اعتماد به برند از دو بعد متفاوت در حوزه روانشناسى و ورئ

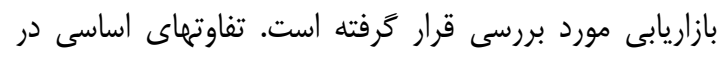

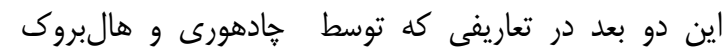

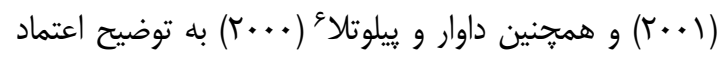

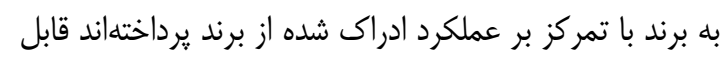

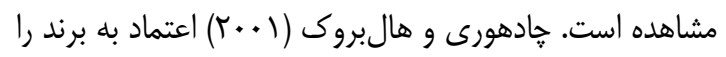
"تمايل مصرف كننده عادى براى داشتن اعتماد بر توانايى برند

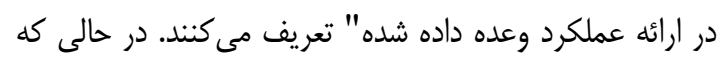

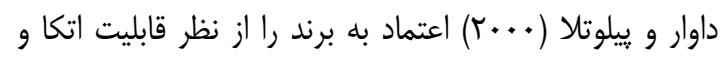

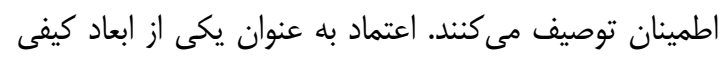

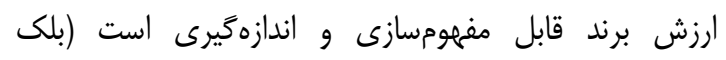

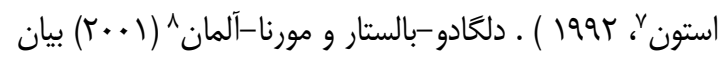

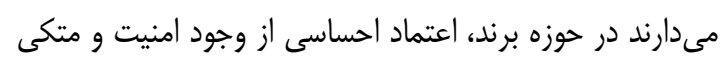

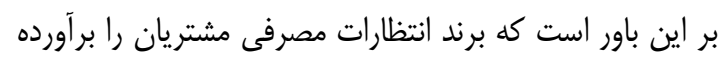

\footnotetext{
${ }^{6}$ Dawar \& Pillutla

7 Blackston

${ }^{8}$ Delgado-Ballester and Munuera-Aleman
}

هرجند همخنان اجماعى در اينباره وجود ندارد (جيفكى و

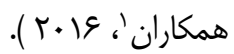
مفهوم برند و برندسازى براى شركتهاى ارائددهنده خدمات

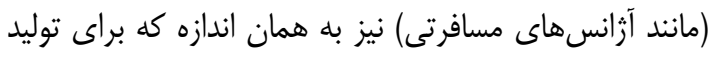

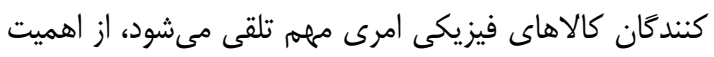

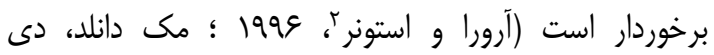

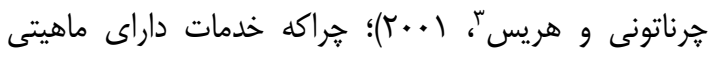

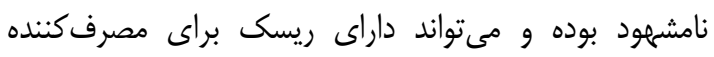

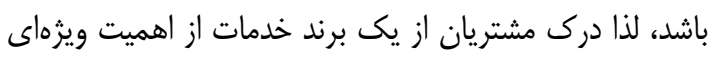

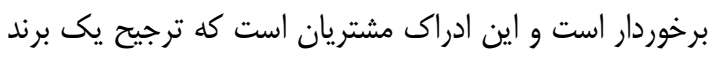

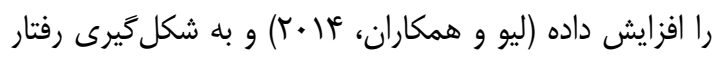

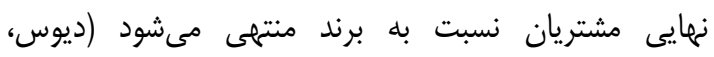

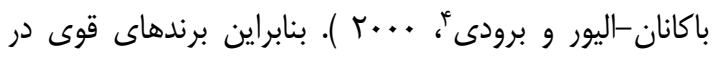

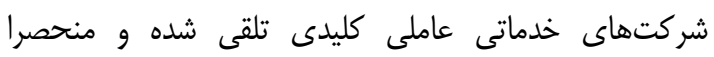

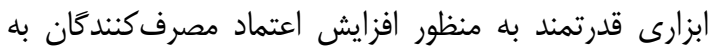

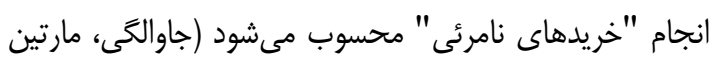

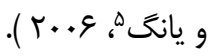

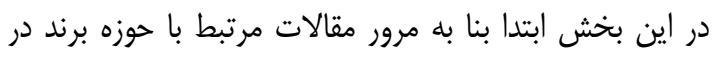

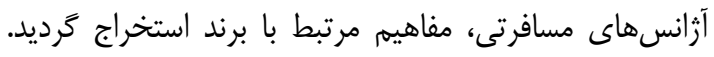

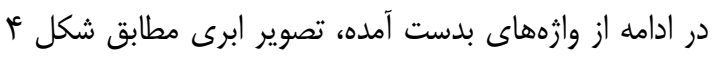

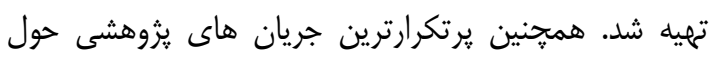

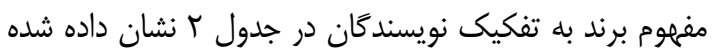

است.

شكل ع. نمايش ابر لغات حاصل از تحليل مفاهيم مرتبط با حوزه برند در آزانس آنهاى مسافر تيى إنى

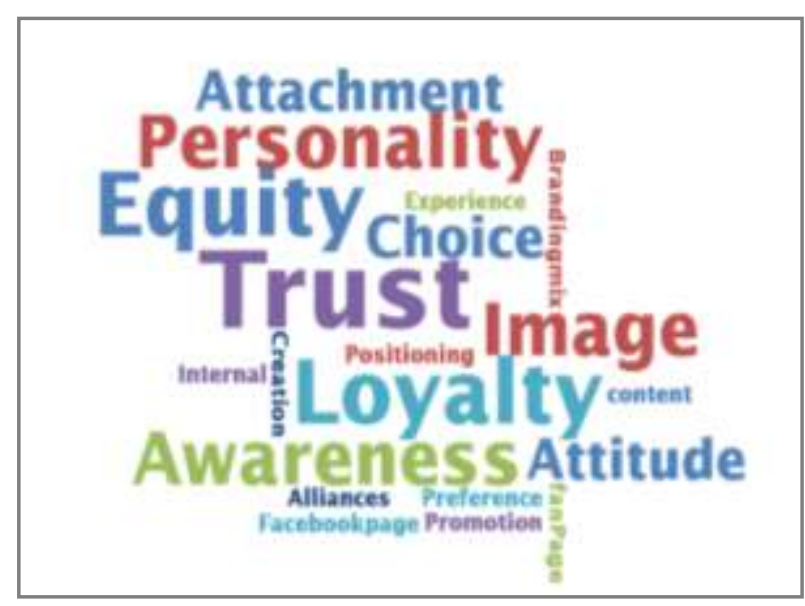

\footnotetext{
Çifci et al.

2 Arora \& Stoner

${ }^{3}$ McDonald, De Chernatony, \& Harris

${ }^{4}$ Davis, Buchanan-Oliver, \& Brodie

Javalgi, Martin, \& Young
} 


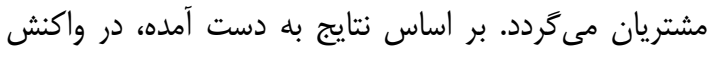
مصرفكننده به يك برند جدرديد برديد آنلاين، ميزان ارتباط ميان

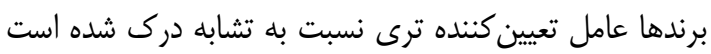

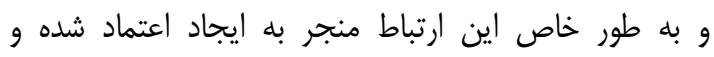

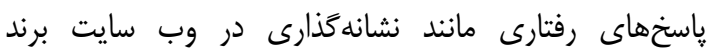

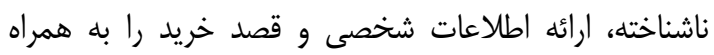

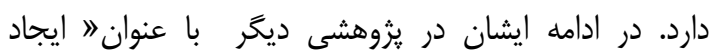
برندهاى آنلاين از طريق اتحاد برندها در اينترنته در راستان درناي

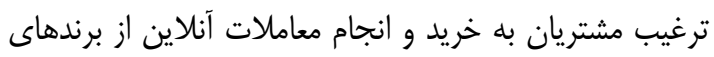

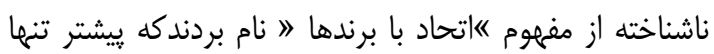

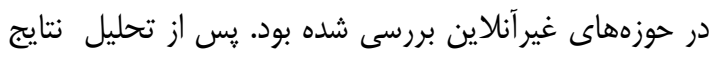

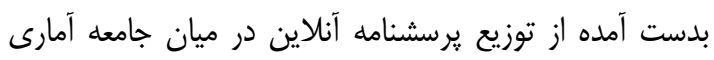

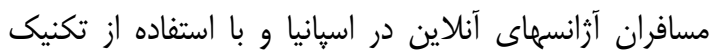

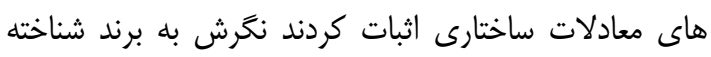

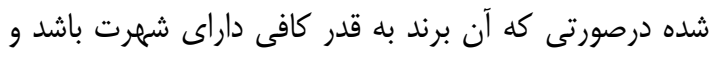

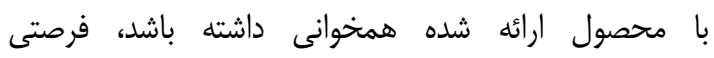

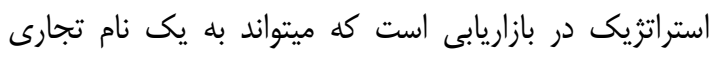

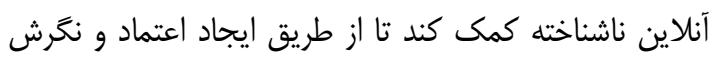

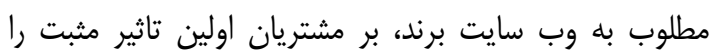
داشته باشد. هاه (عا +r ) در تحقيقى كمى از نوع طولى \& با عنوان " سير

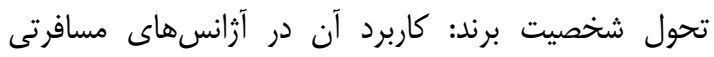

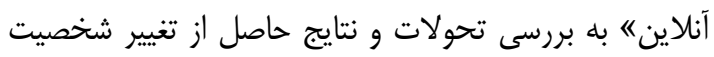

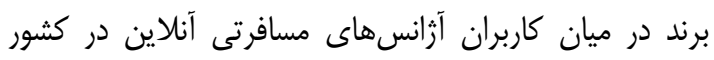

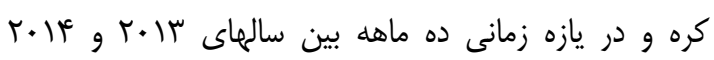

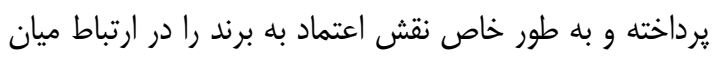

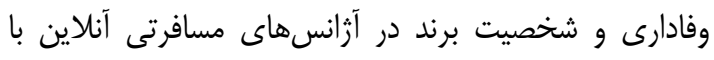
استفاده از تحليل معادلات ساختارى مورد بررسى قرارداديت دراداند.

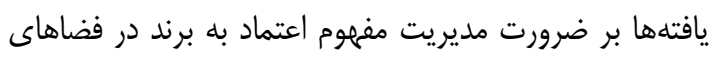

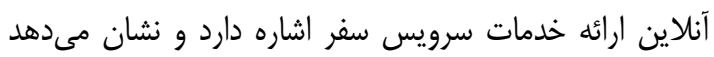

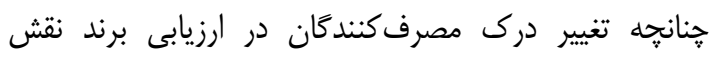

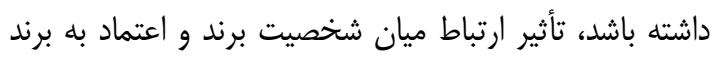

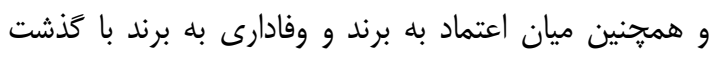

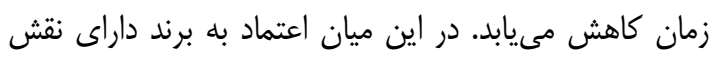

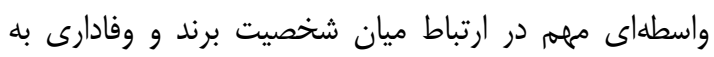

\footnotetext{
${ }^{5} \mathrm{Ha}$

${ }^{6}$ Longitudinal Study
}

خواهد ساخت.از طرفى 》اعتماده در كردشكرى و در آزانس هاى مسافرتى نيز موضوعى حياتى است خراكه اولا به دليل

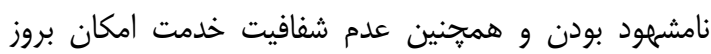

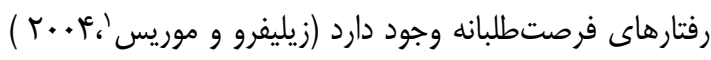

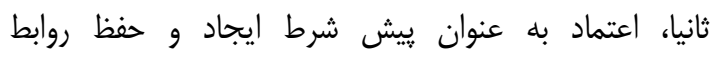

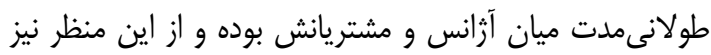

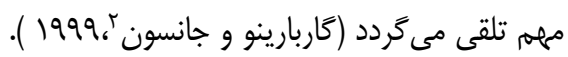

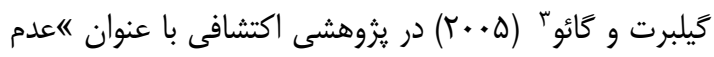

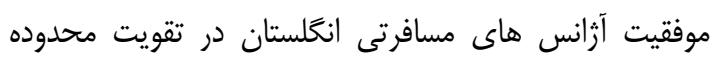

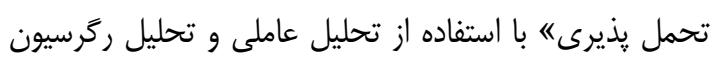

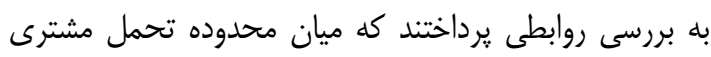

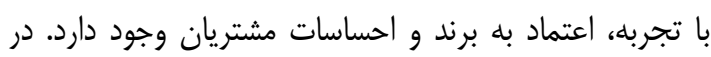

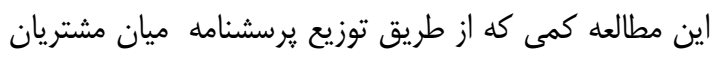

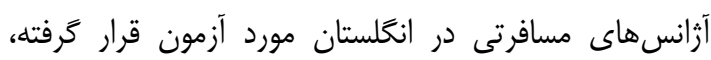

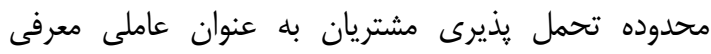

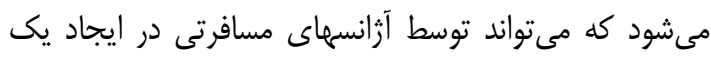

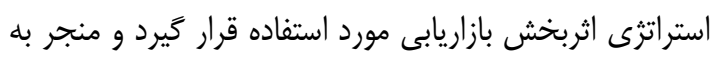

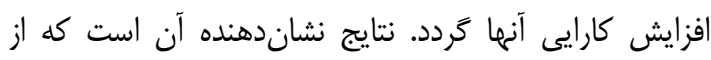

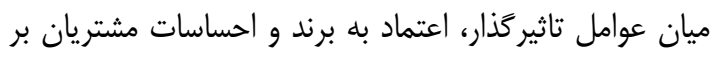

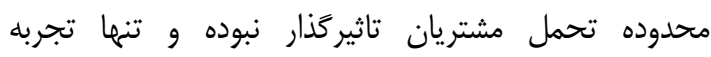
مشتريان است كه با اين مفهوم در ارتباط است.

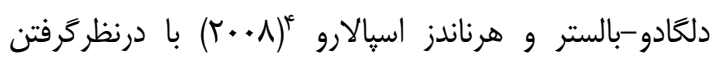

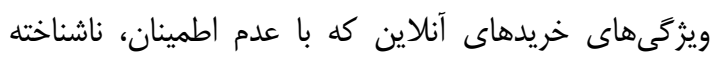

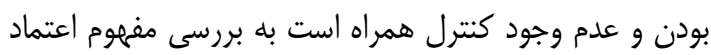

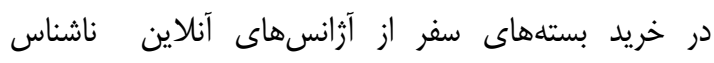

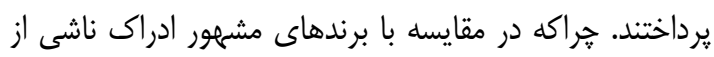

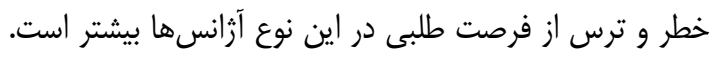

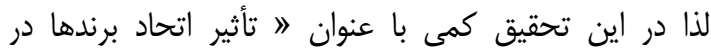

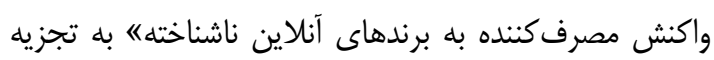

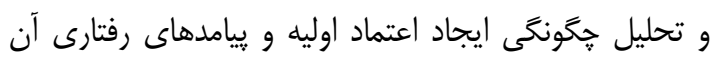

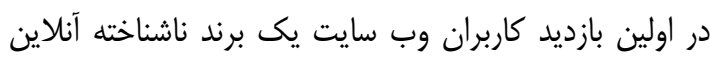

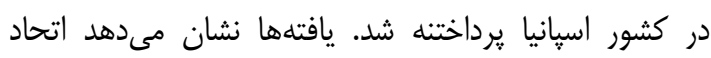

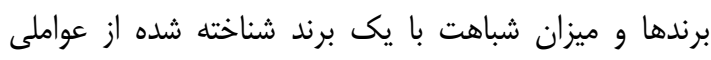
است كه منجر به افزايش اعتماد به برند و تقويت قصد بند رفتارى

\footnotetext{
${ }^{1}$ Zillifro \& Morais

${ }^{2}$ Garbarino \& Johnson

${ }^{3}$ Gilbert \& Gao

${ }^{4}$ Delgado-Ballester \& Hernández-Espallardo
} 
بوده و محتواى ارائه شده در يلتفرم از كيفيت بالايى برخوردار

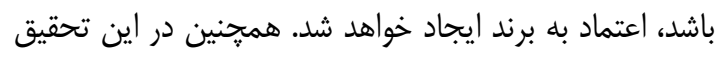

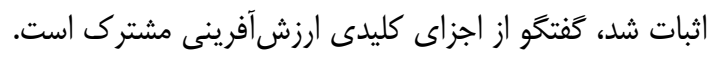

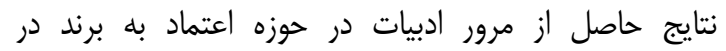

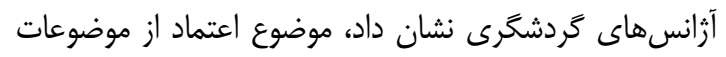

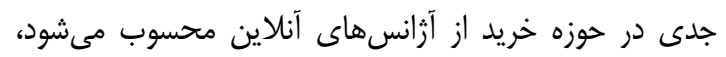

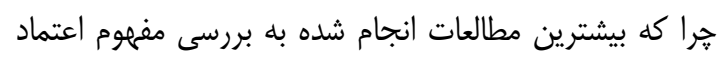

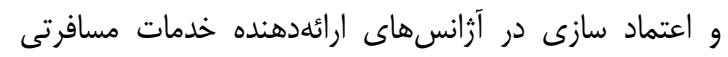

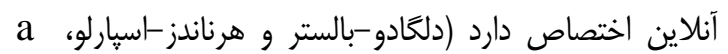

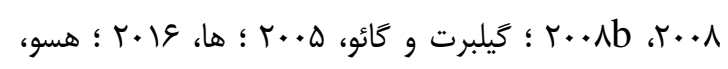

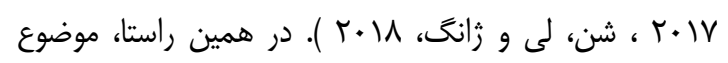

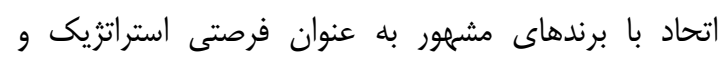

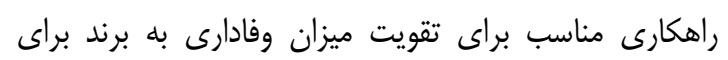

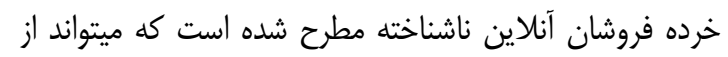

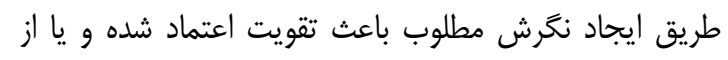

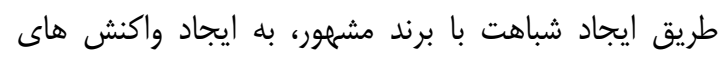

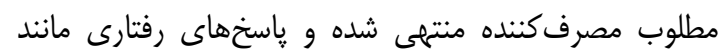

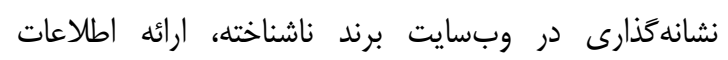

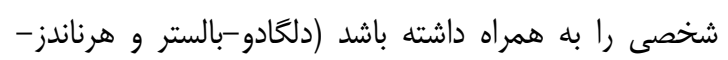

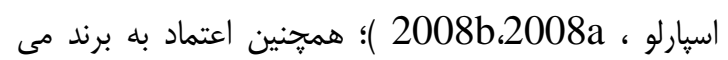

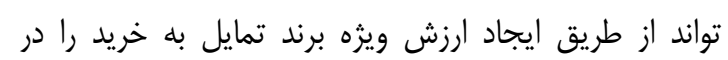

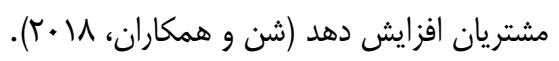

همجنين براى ايجاد اعتماد به برند براى وبسايت هاى

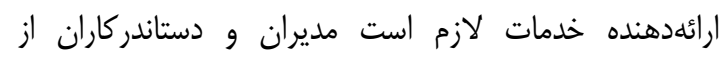

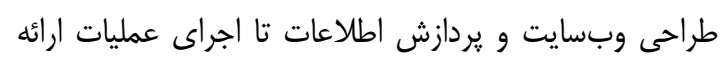

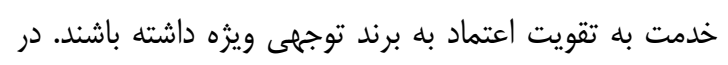

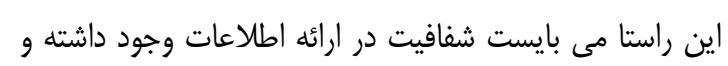

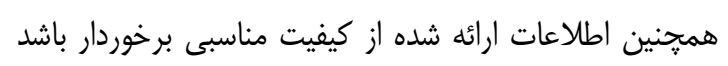

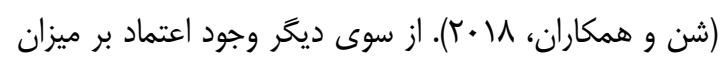

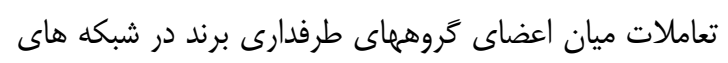

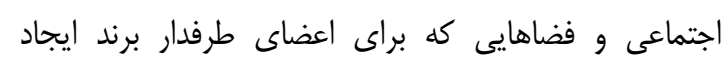

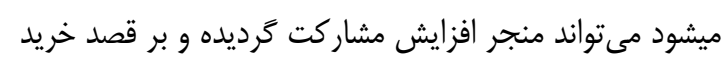

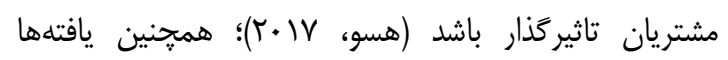

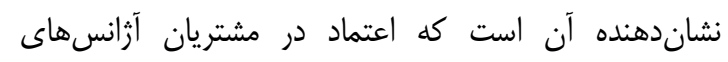

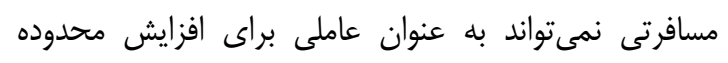

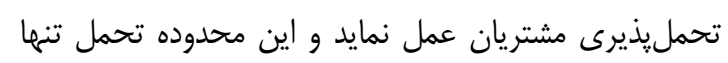

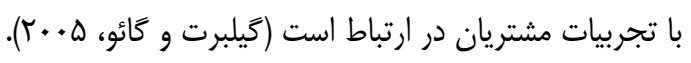

\section{ارزش ويزه برند}

ارزش ويزه برند كه بـراى اولين بار در دهأ . •191 شكل
برند بوده و ارتباط قوى ميان وفادارى و اعتماد به برند وجود دارد

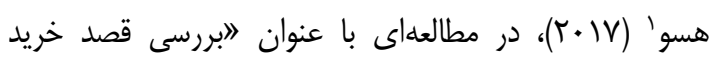

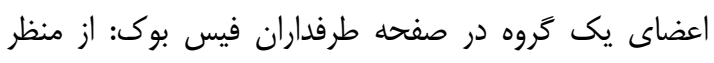

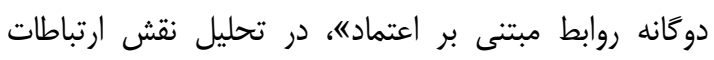

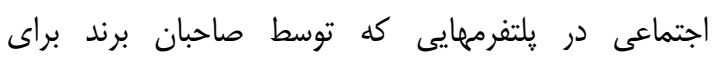

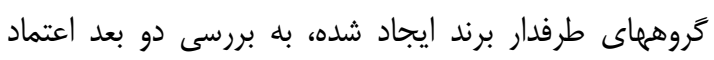

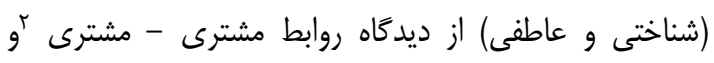

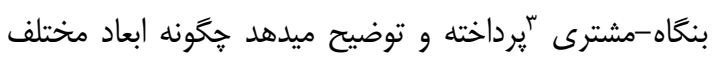

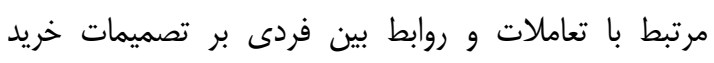

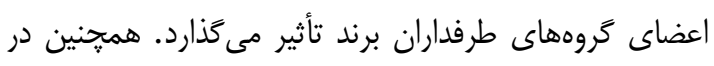

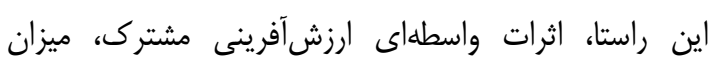

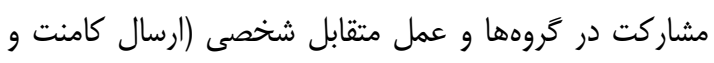

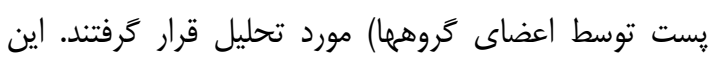

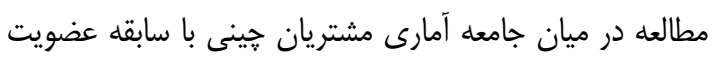

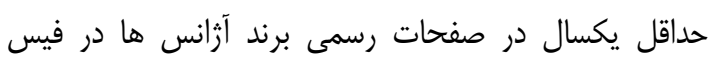

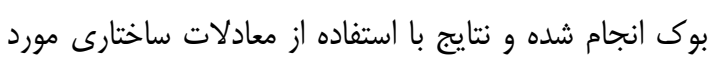

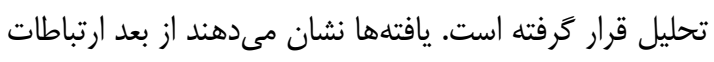

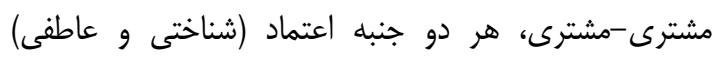

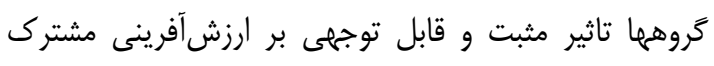

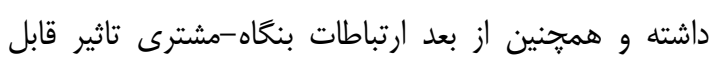

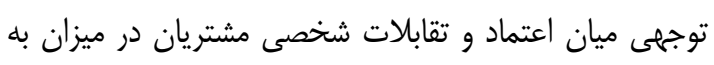

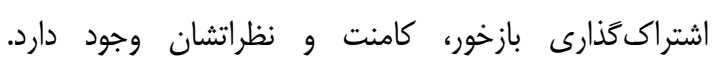

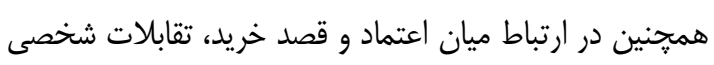

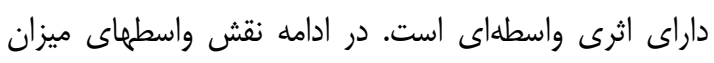

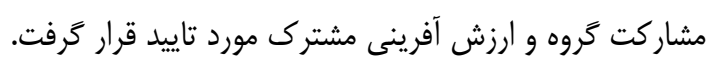

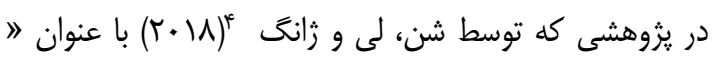

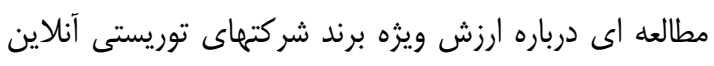

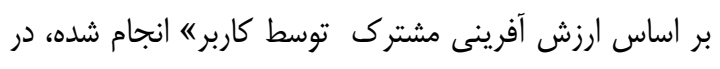

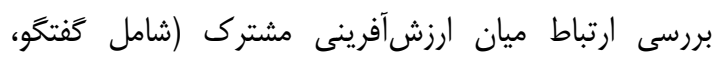

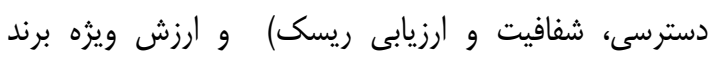

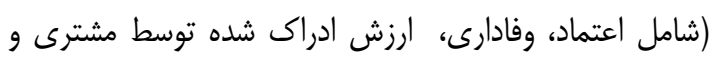

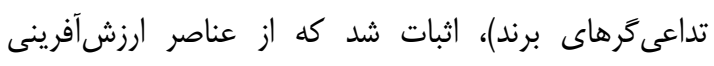

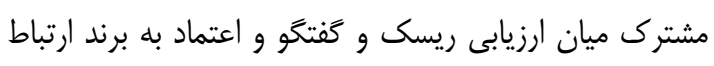
برقرار نيست و تنها رابطه قوى ميان شفافيت و واعتماد به به برند

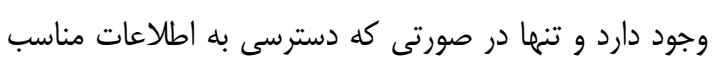

\footnotetext{
${ }^{1} \mathrm{Hsu}$

${ }^{2}$ Customer To Customer (C2C)

${ }^{3}$ Business To Customer (B2C)

${ }^{4}$ Shen, Li, \& Zhang
} 
اين مطالعه مبتنى بر مدل آكر (1999) به ارائه مدل ارزش

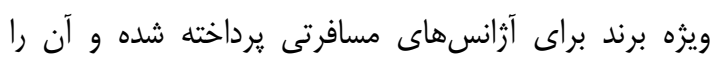

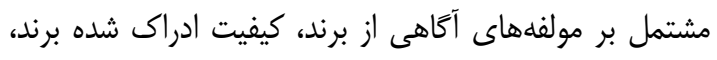
تداعى

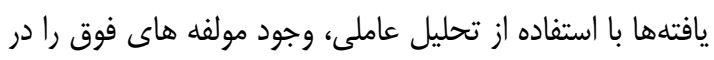
بيان مفهوم ارزش ويثه برند و مديريت برند تاييد مىنمايد.

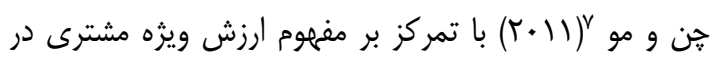

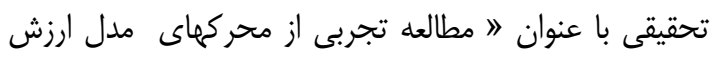

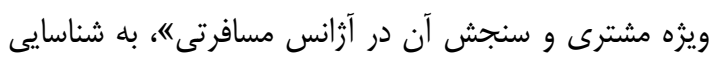
و سنجش محركهاى اين مدل شامل ارزش ويزه برند، ارزش ونش

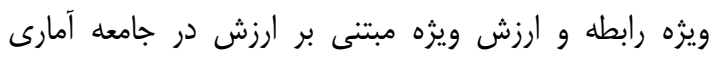

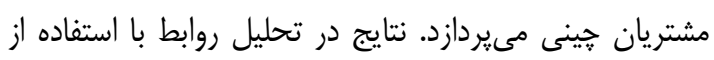

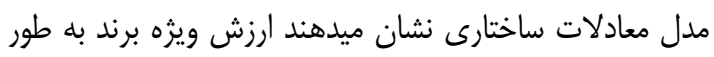

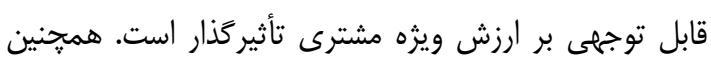

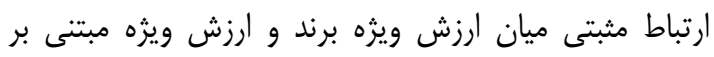

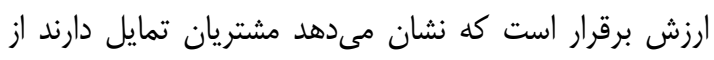
خدمات آزانسهاى مسافرتى با برندهاى شناخته شده استفاده

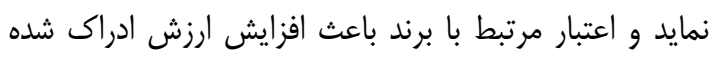

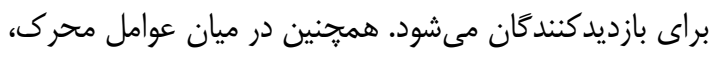

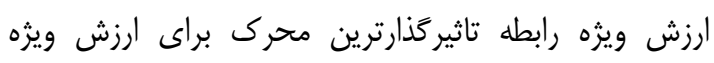
مصرف كننده است. همجنين همانكًونه كه در مطالعات مرتبط با اعتماد بيان شد،

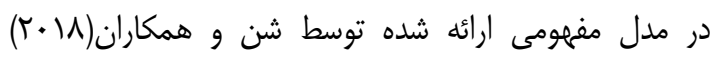

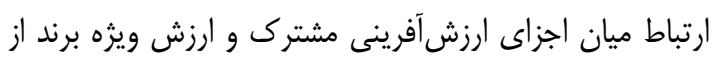

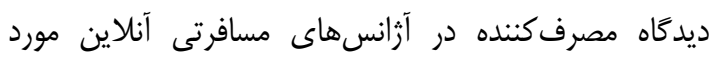

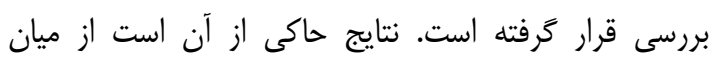

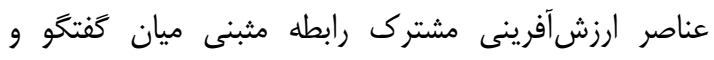

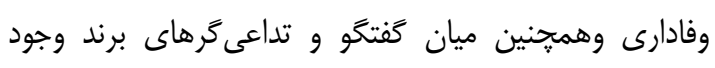

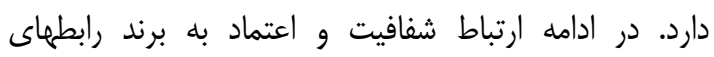

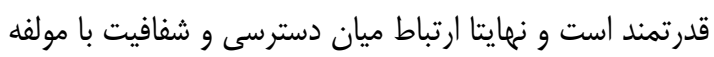
ارزش ادراك شده مثبت معنادار است. بنابراين اثبات شد ميان

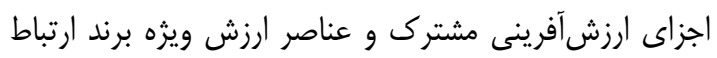

$$
\text { برقرار است. }
$$

مطابق با مرور ادبيات موجود ، ارزش ويثه برند به به عنوان

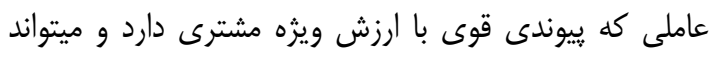

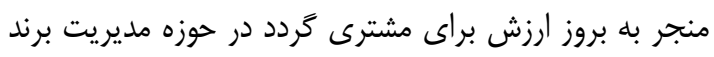

${ }^{7}$ Chen \& Mo
گرفت، امروزه به يكى از مفاهيم مهم بازاريابى در هر دو حوزه

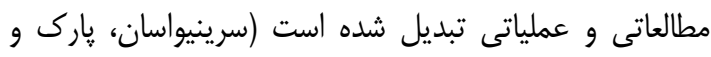

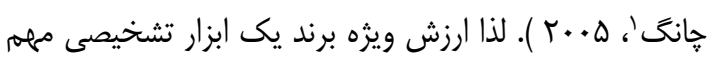

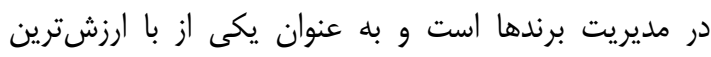

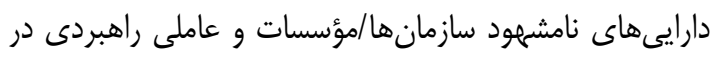

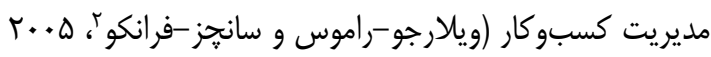

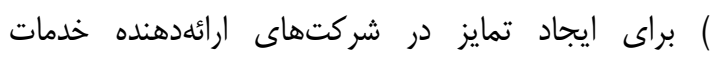
يذيرفتهشده و موردتوجه مديران و و محققان قرارگترفته

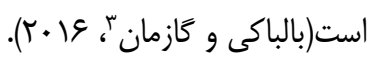

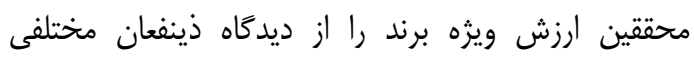

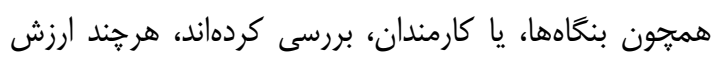

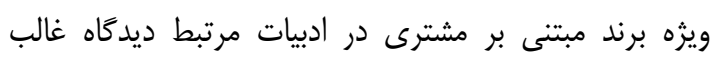

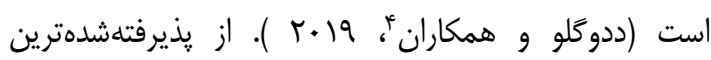

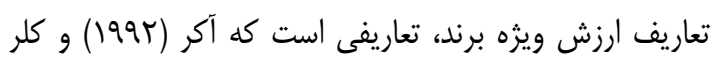

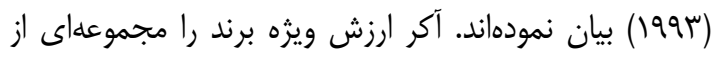

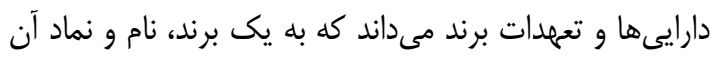

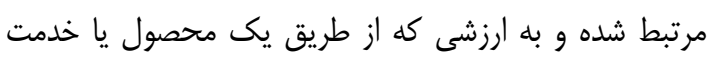
به مشتريان يك بنغاه ارائه مى شود افزوده و يا از آن مى كلى كاهد.

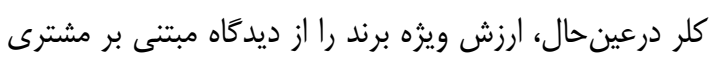

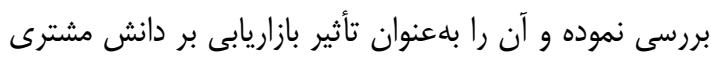

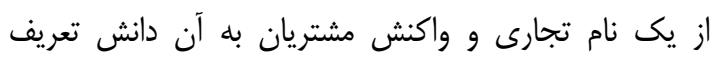

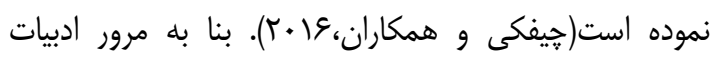
موجود، مطالعات زيادى در حوزه خدمات و بـ به طور خاص

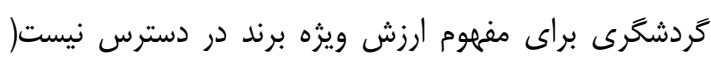

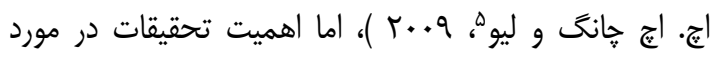

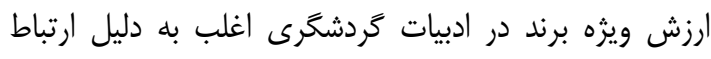
قوى آن با استراتزى بازاريابى و مزيت رقابتى، مورد تأكيد قرار مى گيرد (كى. ال. كلر، 9 +.

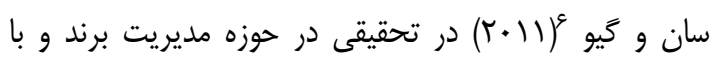

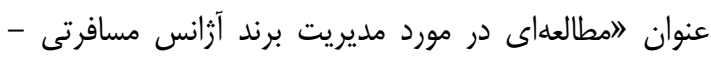

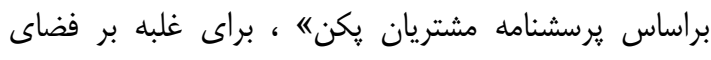

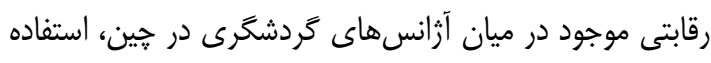

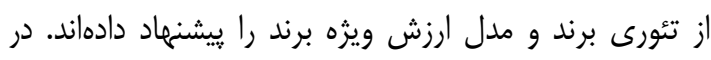

\footnotetext{
${ }^{1}$ Srinivasan, Park, \& Chang

${ }^{2}$ Villarejo-Ramos \& Sanchez-Franco

${ }^{3}$ Baalbaki \& Guzmán

${ }^{4}$ Dedeoğlu et al.

${ }^{5}$ H. H. Chang \& Liu

${ }^{6}$ Sun \& Gui
} 


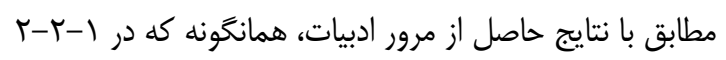

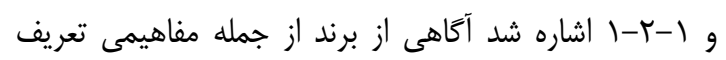

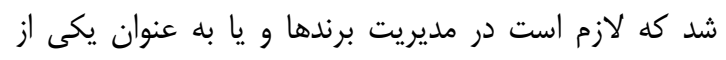

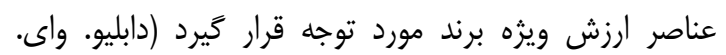

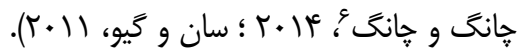

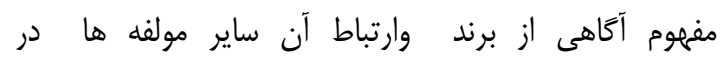

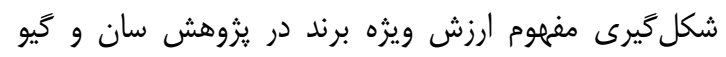
(r+11)

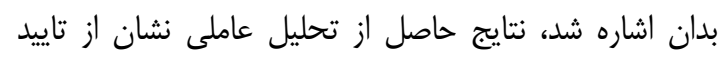

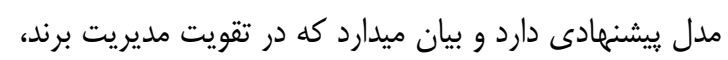

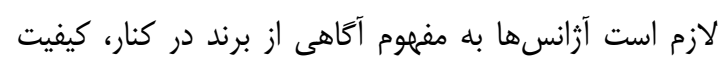

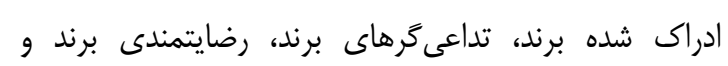

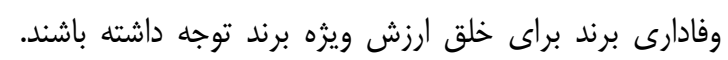

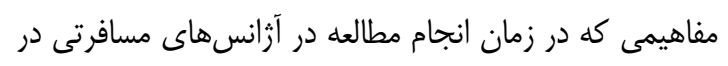
كشور جين توسط مديران و صاحبان آزانس هان مانى مسافرتى

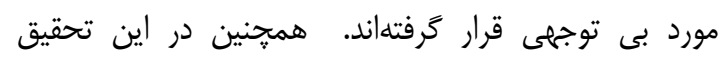

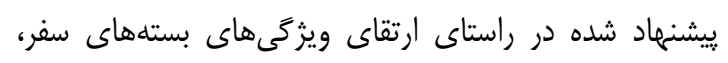

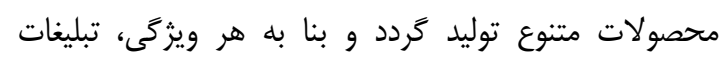

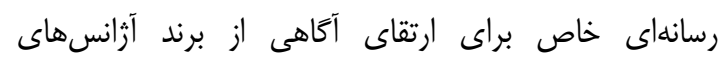
مسافرتى صورت يذيرد.

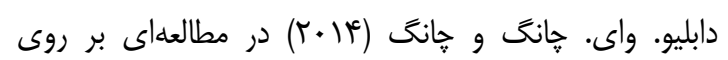

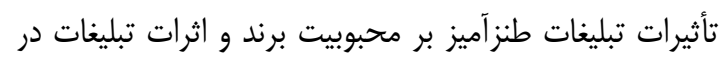

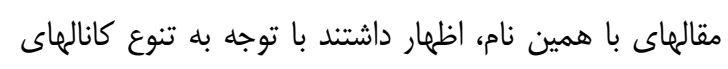

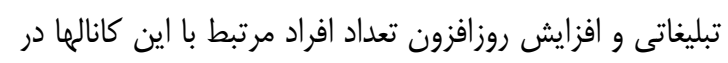

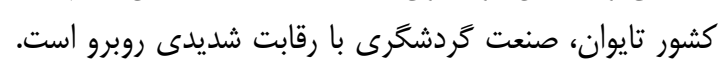

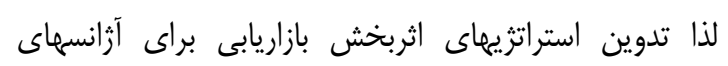

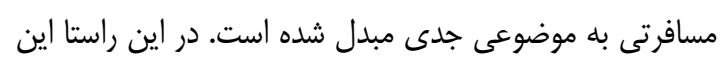

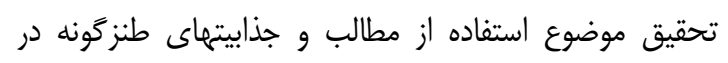

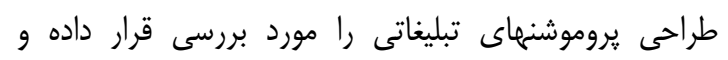

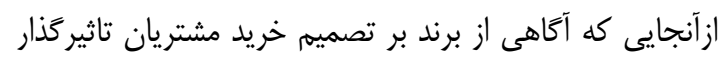

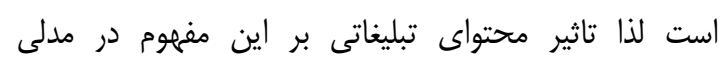

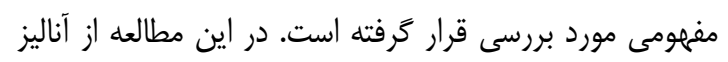

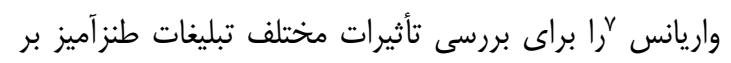

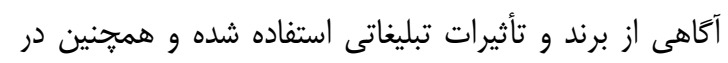

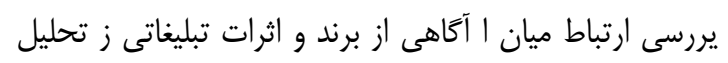

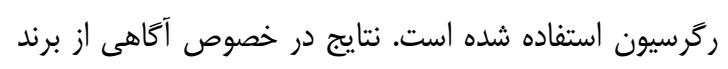

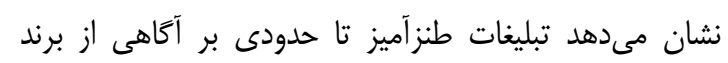

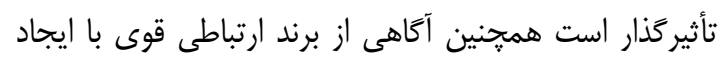

${ }^{6}$ W. Y. Chang \& Chang ${ }^{7}$ ANOVA

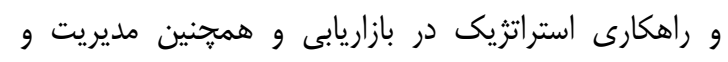

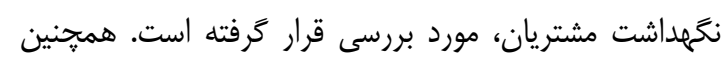

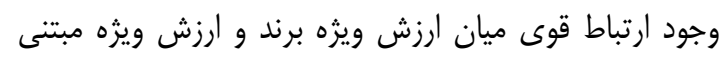

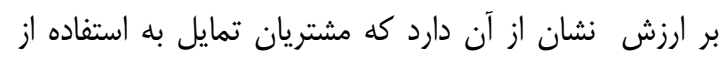

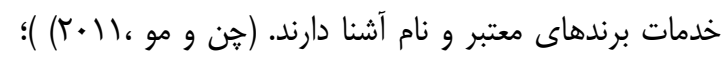

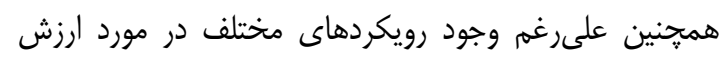

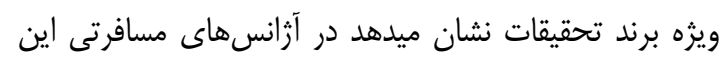

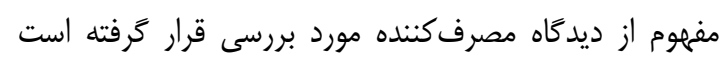

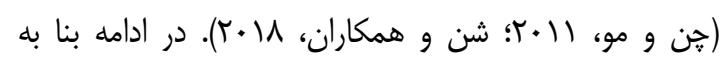

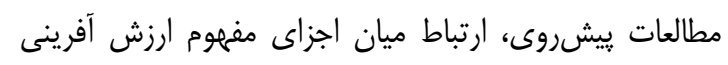

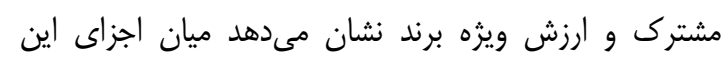

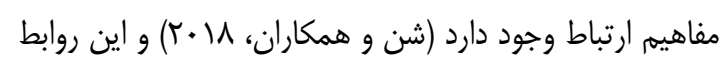

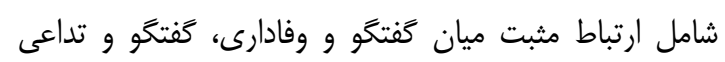

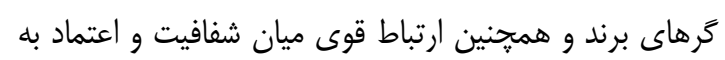

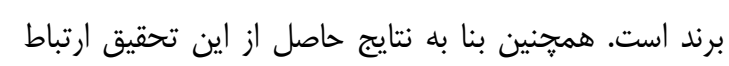

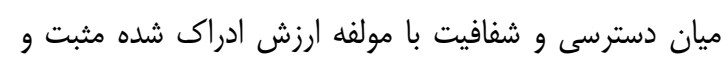

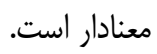

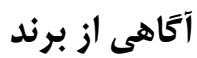

آكَاهى از برند در واقع دانش، آكاهى وآن شناختى است كه داند

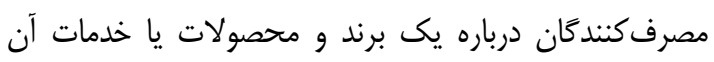

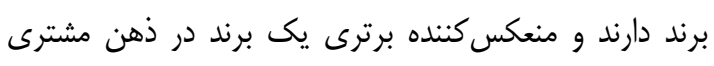

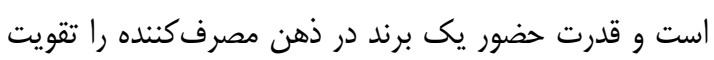

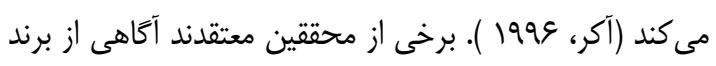

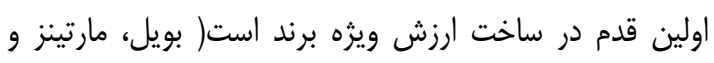

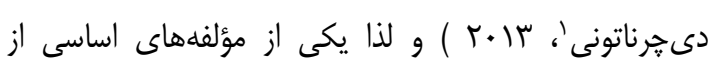

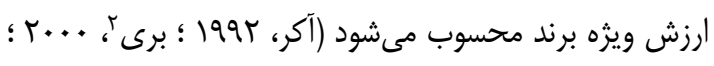

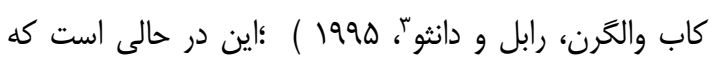

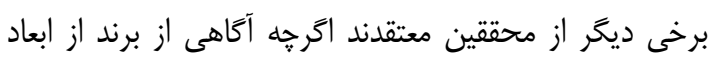

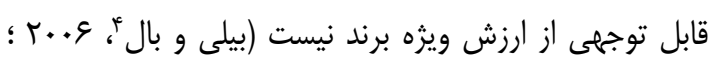

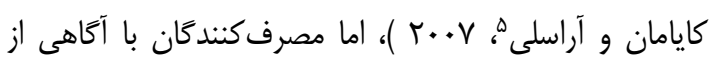

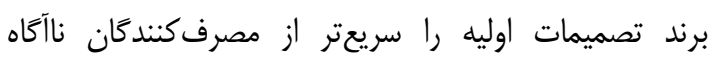

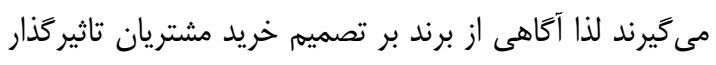

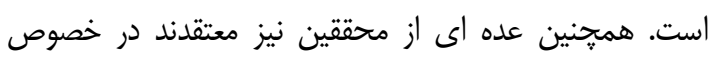

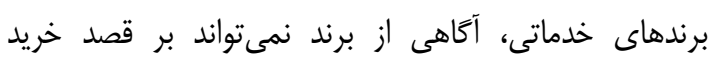

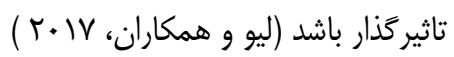

\footnotetext{
${ }^{1}$ Buil, Martínez, \& De Chernatony

${ }^{2}$ Berry

${ }^{3}$ Cobb-Walgren, Ruble, \& Donthu

${ }^{4}$ Bailey \& Ball

${ }^{5}$ Kayaman \& Arasli
} 
تبليغاتى تاثير گذار باشد، بر ايجاد نخرش به برند نيز تاثير گذار

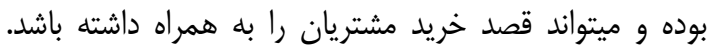

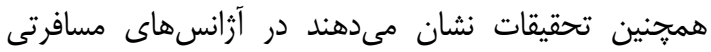

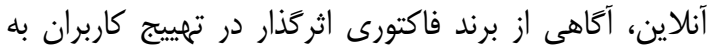

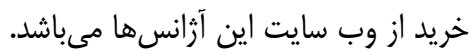

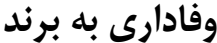

وفادارى به برند مفهوم جديدى نيست، اما اين مفهوم در بر بدر سالهاى اخير، به ويزه در صنعت گردشگرى، مورد توجه

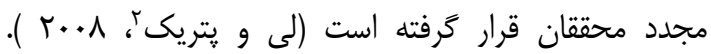
وفادارى به برند كه به عنوان تابعى از ياسخ رفتارى و نحَرش

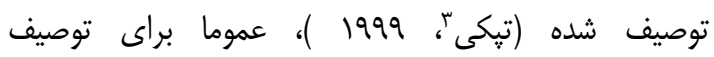
ويثزىهاى مشتريانى كه تعهد زيادى به يكى برند خاص دارند و آن برند را به ساير برندها ترجيح مى مدهند، مورد ادراك قرار

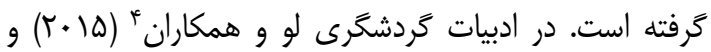

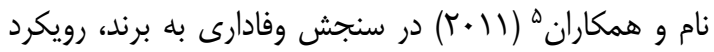
رفتارى را به شدت مورد انتقاد قرار مىدهند. آنها استدلال

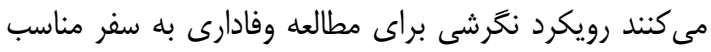

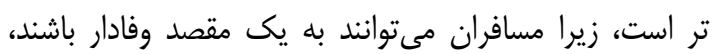

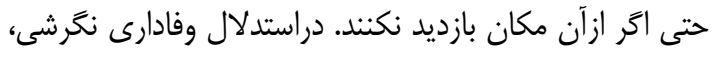

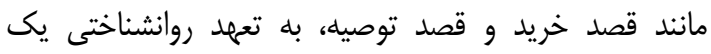

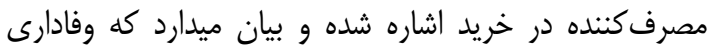

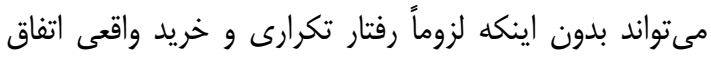

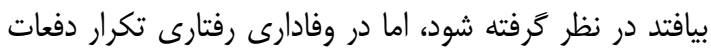

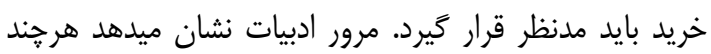

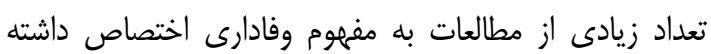

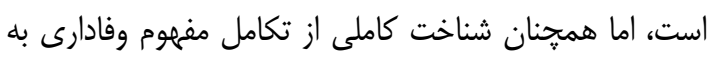

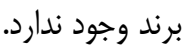

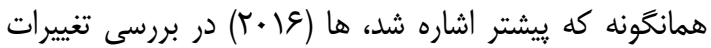

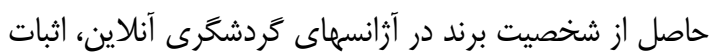

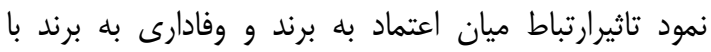

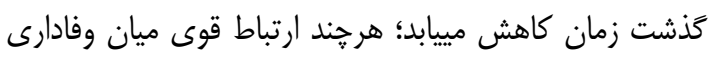
و اعتماد به برند وجود دارد. يافتهها نشان داد كه توانايى هني تقويت شخصيت برند نقش مهمى در ايجاد ارتباط بين بين

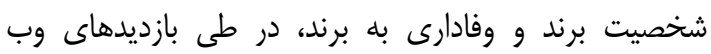

\footnotetext{
${ }^{2}$ Li \& Petrick

${ }^{3}$ Tepeci

${ }^{4} \mathrm{Lu}$ et al

${ }^{5} \mathrm{Nam}$ et al
}

نَرش برند و همجنين ايجاد نخرش تبليغاتى ناشى از اثرات

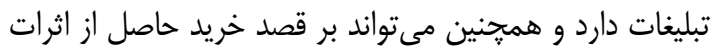

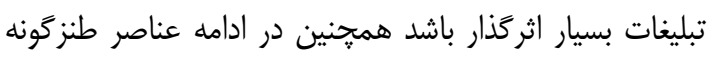
تا حدودى با اثرات حاصل از تبليغات ارتباط دارند.

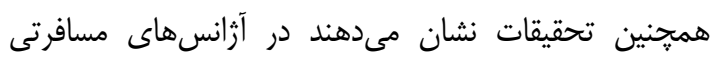

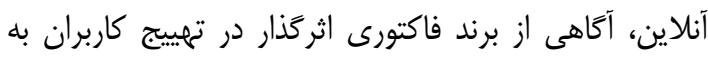

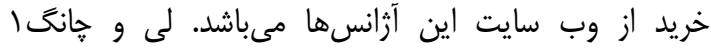

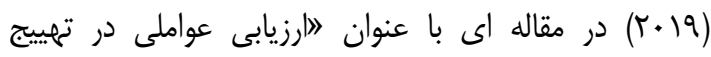

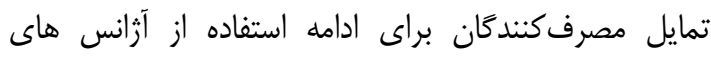

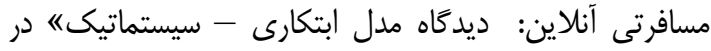

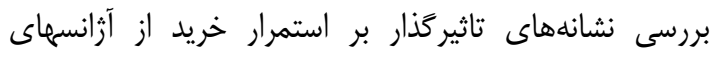

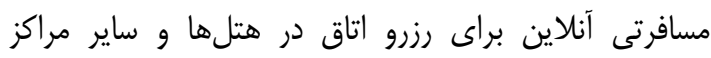

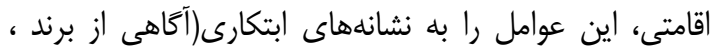

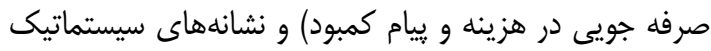

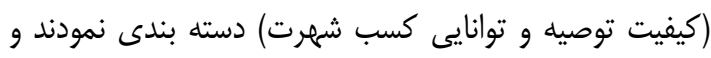

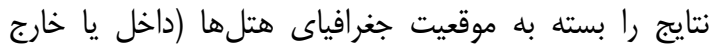

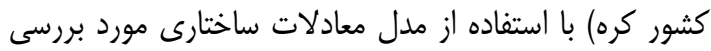

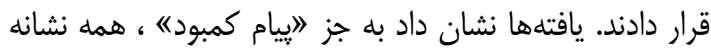

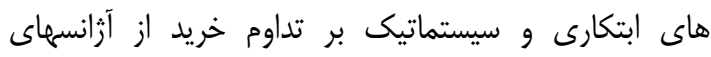

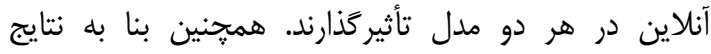

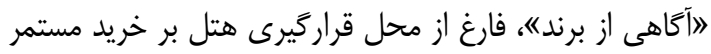

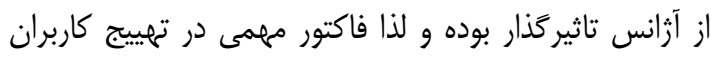
به خريد محسوب مى شود، هرجند اين نتيجه در مورد مورد صرفهجويى در هزينه (نشانه ابتكارى) و كيفيت هرديل توصيله(نشانه

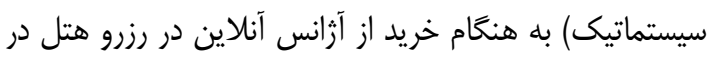

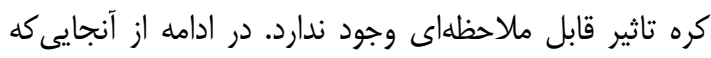

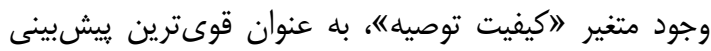

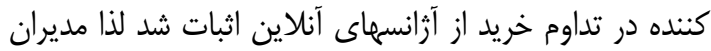

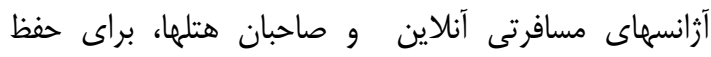

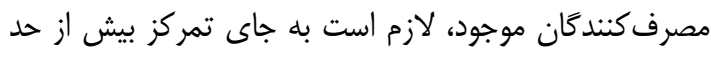

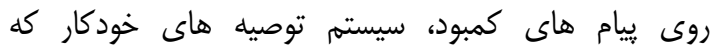

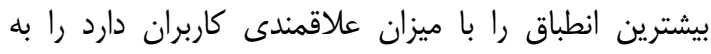
لحاظ ميزان كيفيت توسعه دهند.

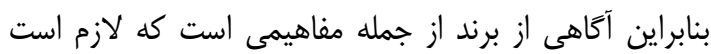

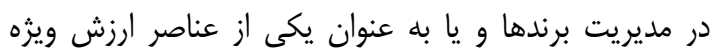

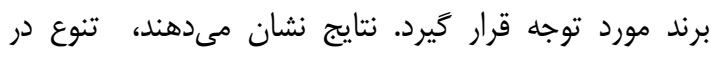

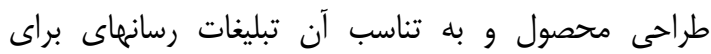

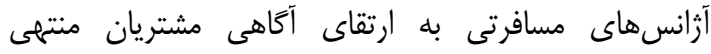

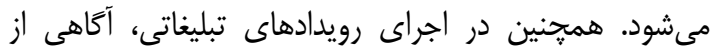
برند علاوه برآنكه مىتواند بر محتواى طنز آميز برنامههاى

${ }^{1}$ Lee \& Chung 
بر ميزان وفادارى مشتريان و جايكاه يابى برند دارد. مضافا

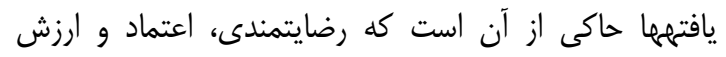

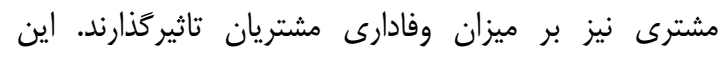

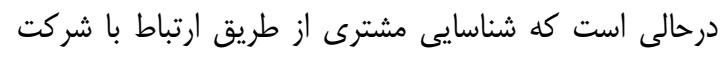

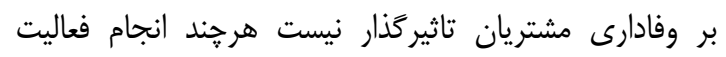

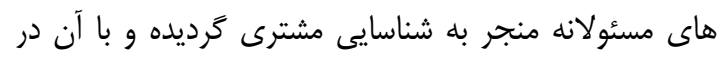

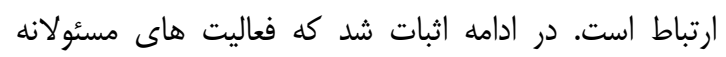

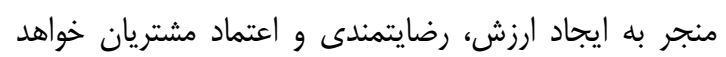

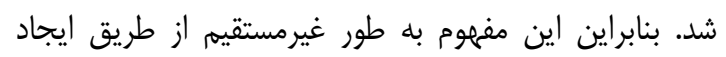

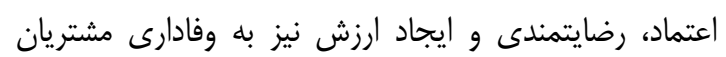

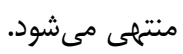

بنابراين بر اساس مرورى كه در ادبيات در مورد مفهوم

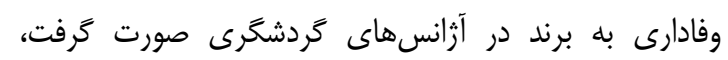

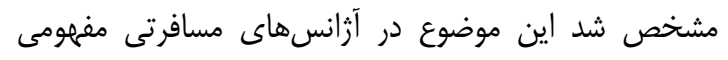

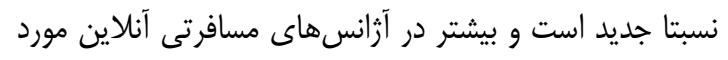

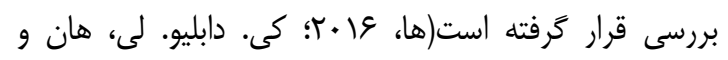

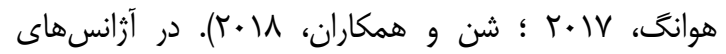

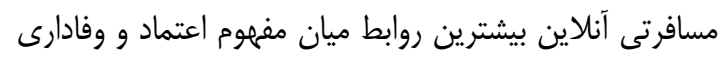

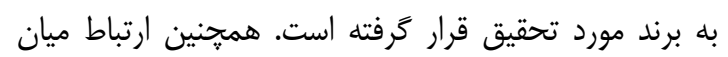

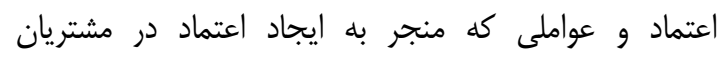

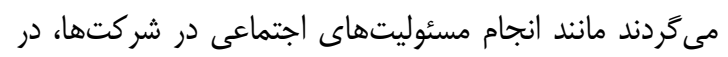

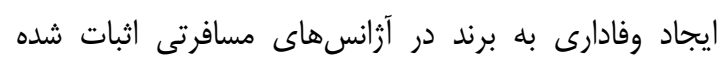

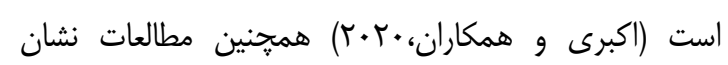

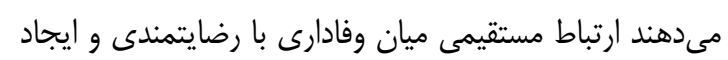
ارزش براى مشترى وجود دارد (اكبرى و همكاران، •r.r.

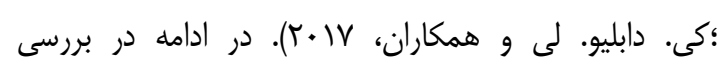

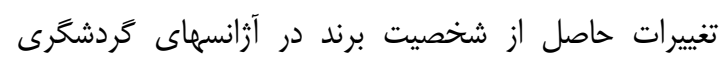

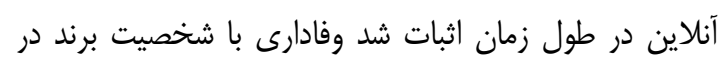

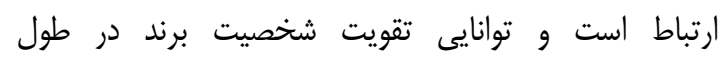
بازديدهاى وب سايت به صورت آنلاين نقش مهمى در در ايجاد

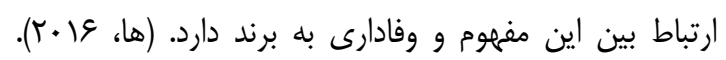

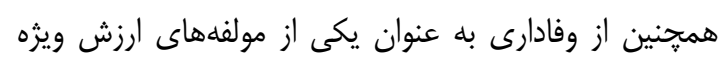

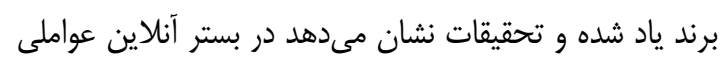

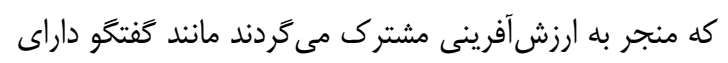

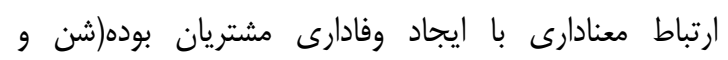

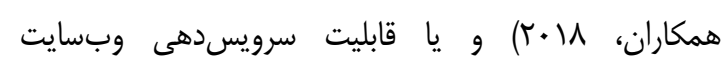
آزانسهاى مسافرتى آنلاين به لحاظ فنى و عملكردى مئى ميتواند از طريق ايجاد رضايتمندى كه خود فاكتورى مهانه در ايجاد لهاد

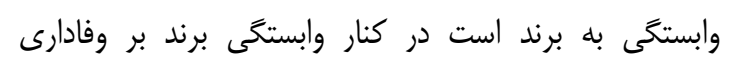

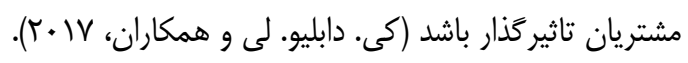

سايت آناين يا دوره هاى مصرف دارد. همجنين در ارتباط ميان شخصيت برند و وفادارى به برند، اعتماد داراى اثرى داري

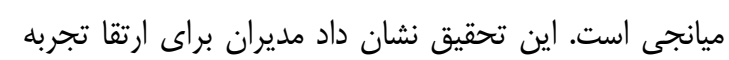

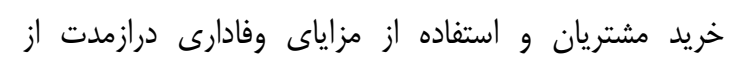

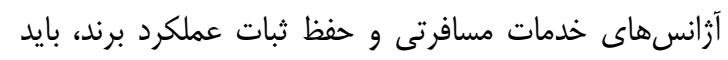

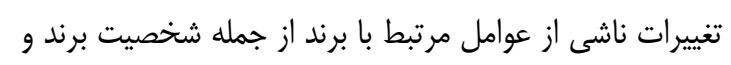

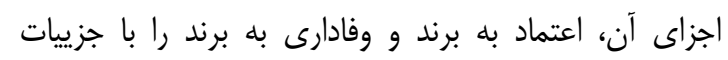

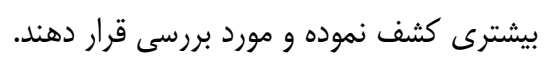

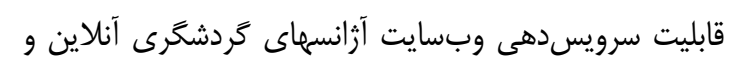
تاثير آن بر ميزان وفادارى مشتريان نيز در تحقيقى كه توسط آنائ

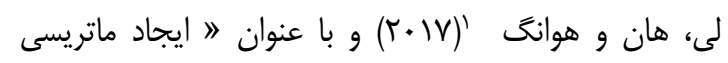

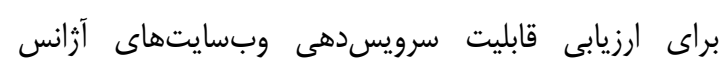

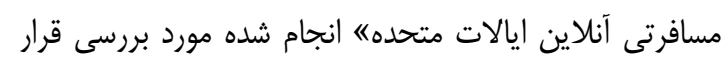

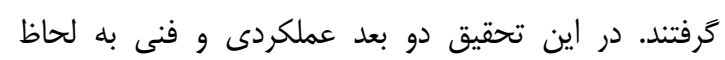

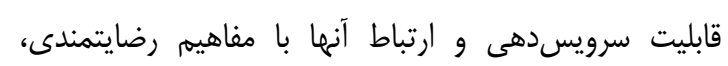

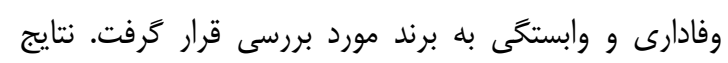
حاصل از تحليل معادلات ساختارى حاكى از آن آن است كه درار درف

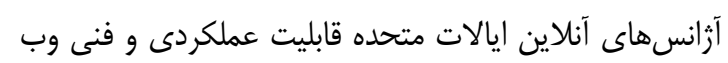

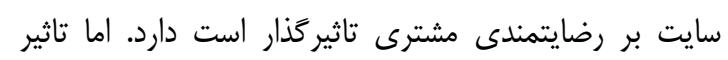

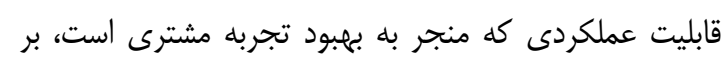

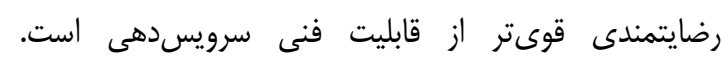

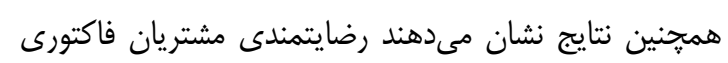

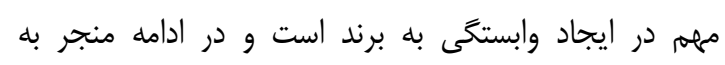

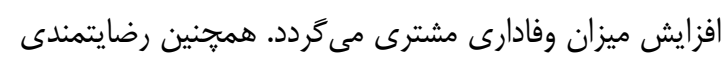

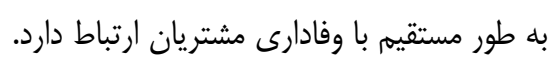

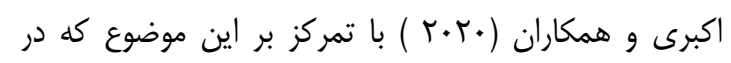

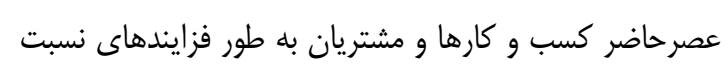

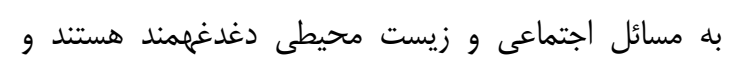

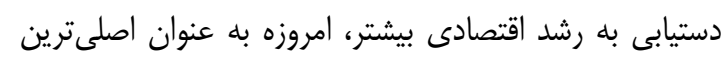

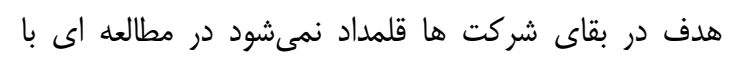

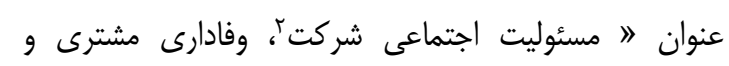

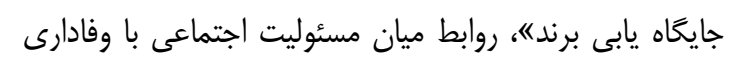

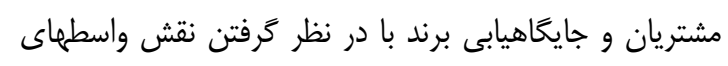

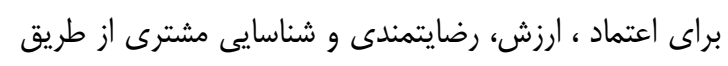

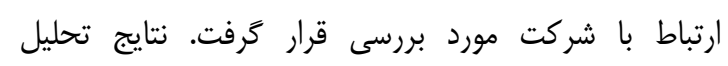

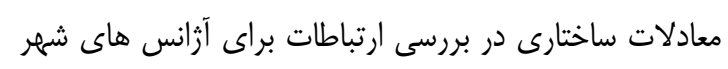

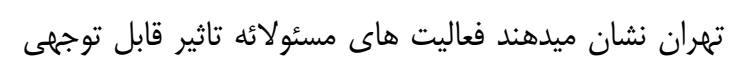

\footnotetext{
${ }^{1}$ K.-W. Lee, Han, \& Hwang

${ }^{2}$ Corporate Social Responsibility (CSR)
} 
جامعه آمارى كه نمونهگيرى در آنها انجام شده و همجنين مراكز علمى و موسسات صاحب امتياز مقالات مطابق با نمودار

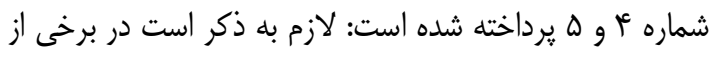
مطالعات محدوده جغرافيايى خاصى مدنظر نبوده و لذا در در آمار مطالعات مورد محاسبه قرار نخرفتهاند.

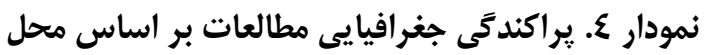
نمونه تيرى

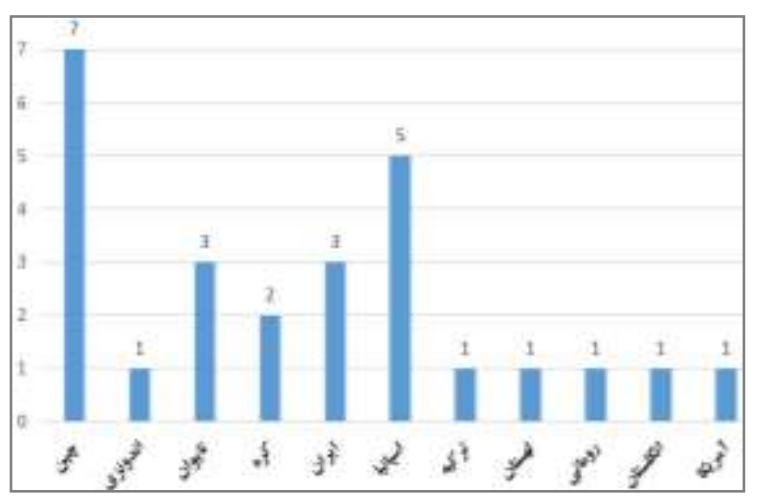

منبع: تحليل نغارندگًان

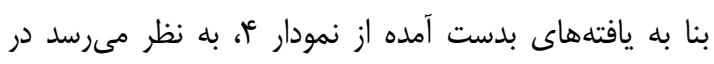

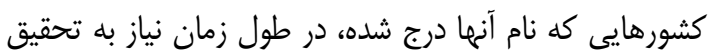
در حوزه برند براى آزانسهاى مسافرتى از سوى محققين، دست اندركاران وصاحبان اين كسب و كار احساس شده است، بران

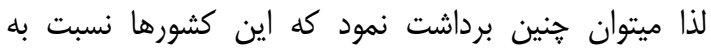

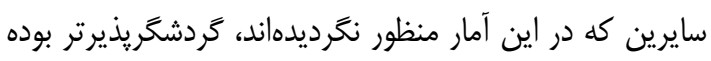

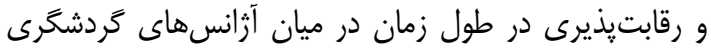

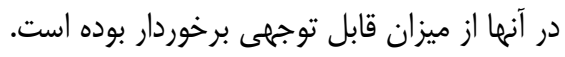

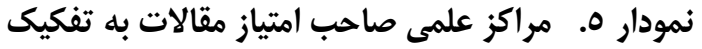
موقعيت جغر افيايى مراكز

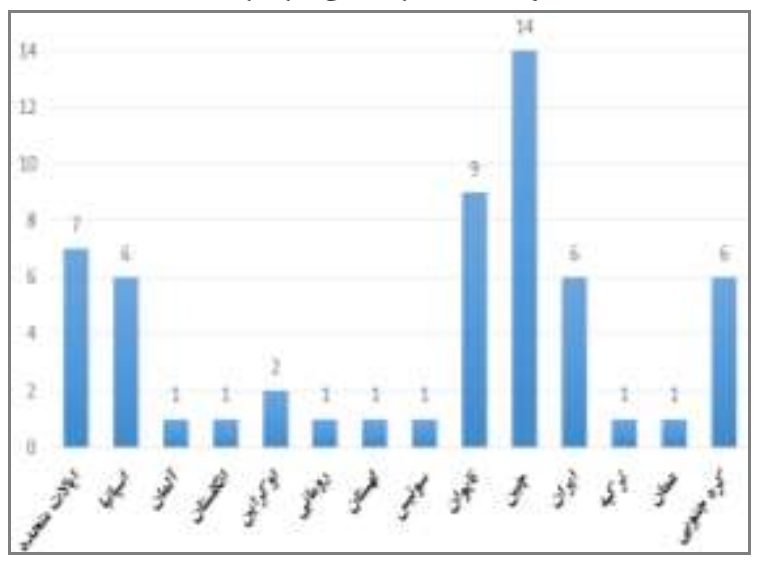

منبع: تحليل نغارندكان

همجنين همانكونه كه از نمودار ه ه ييدا است، بيشترين
تحليل و نتيجه كيرى يس از جمعبندى ادبيات موجود در اين حوزه (بخش دو)، در دري ادامه به تحليل نتايج بدستأمده يرداخته شده است:

\section{خلاصهاى از يافتههاى مقالات مرور شده} با نغاهى روش رشناختى به استراتزىهاى يثوهش (جدول

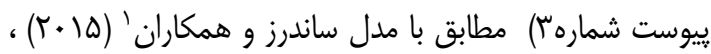
نتايج نشاندهنده آن است كه اكثر تحقيقات انجام شده در اين

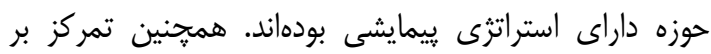

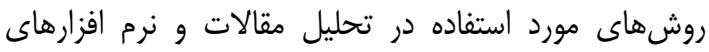
مورد استفاده نشان مىدهد به جز دو مقاله (مقالات ستاره دار

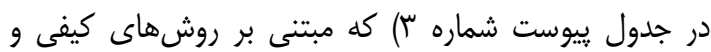

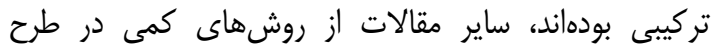

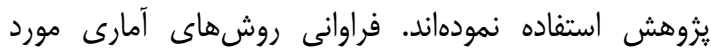

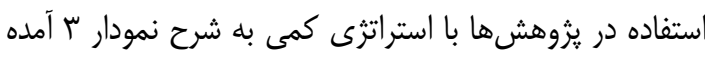

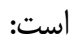

نمودار س. فر اوانى روش هاى كمى مورد استفاده در تحليل مطالعات

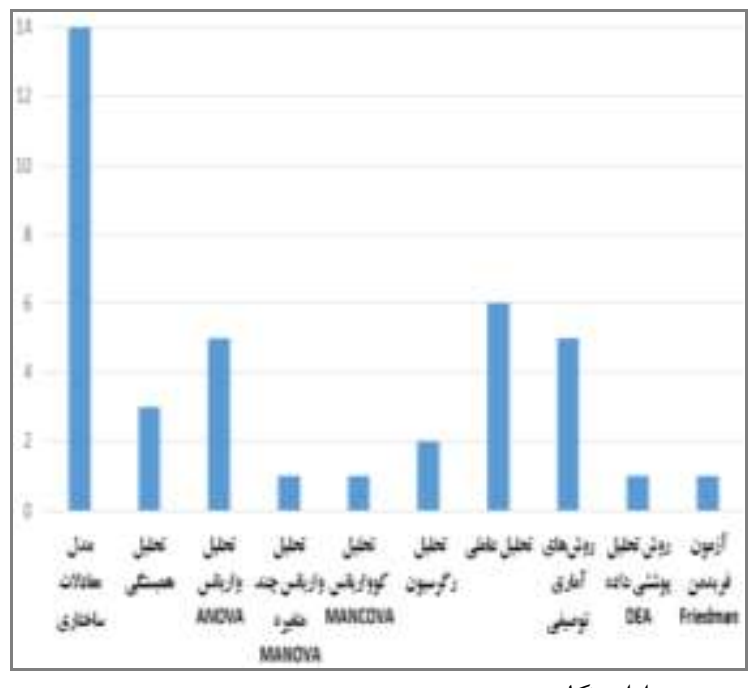

منبع: تحليل نغارنده

همانغونه از نمودارس ييداست، بيشترين نكارنده روش مورد استفاده براى بررسى روابط به مدل معادلات ساختارى اختصاص داشته است، در ادامه تحليل عاملى، تحليل واريانس و وآمار توصيفى در تحقيقات مرور شده، از بيشترين روشهای دهاى مورد استفاده بودهاند. در ادامه به بررسى مطالعات بر اساس :راكندگى جغرافيايى

${ }^{1}$ Saunders M., et al. 
نمودار 7.توسعه زمانى تعداد مقالات شناسايى شده در

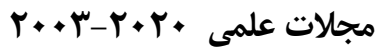

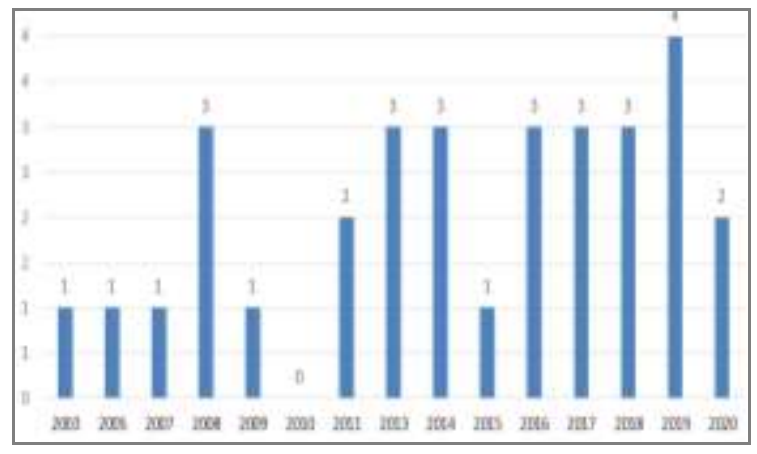

منبع: تحليل نكارندًان

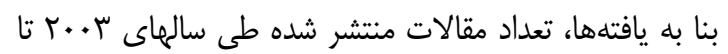

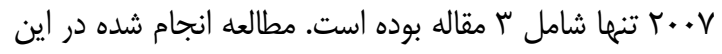

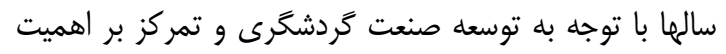

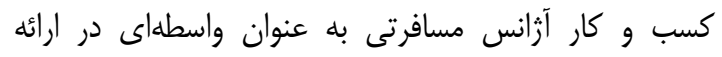

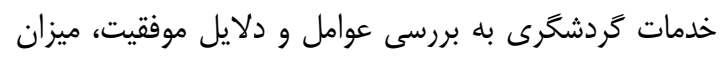

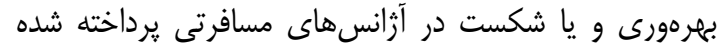

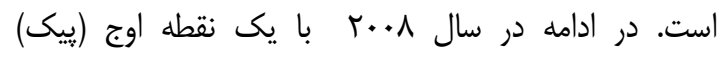

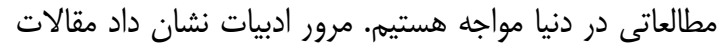

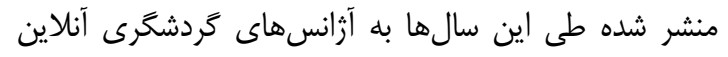

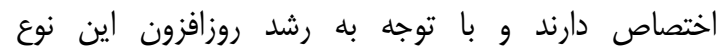

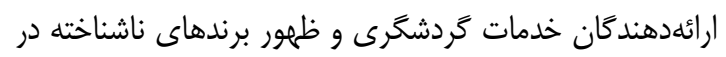

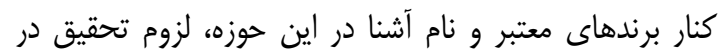

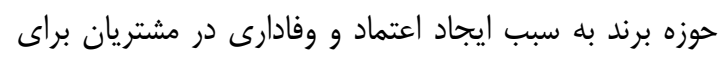

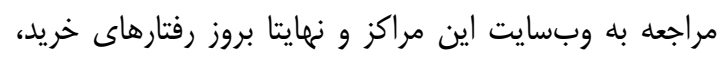

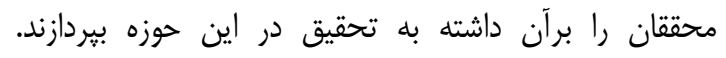

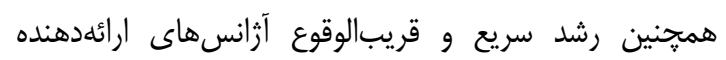

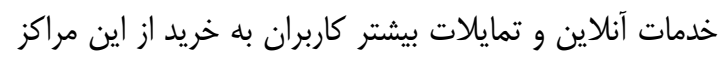

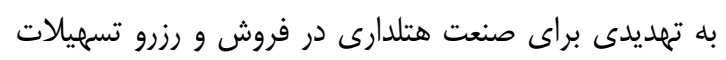

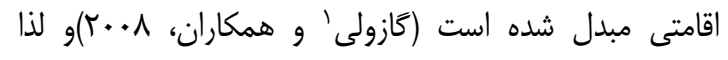

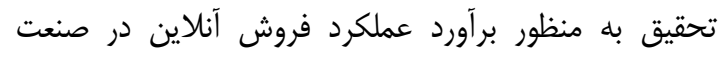
هتلدارى مورد مطالعه قرار ترفته است.

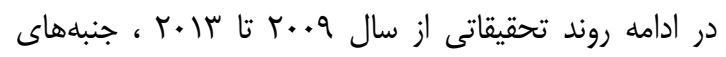

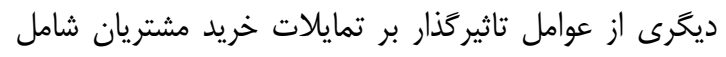

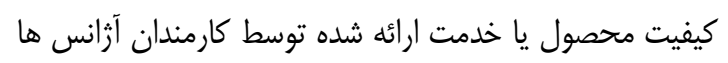

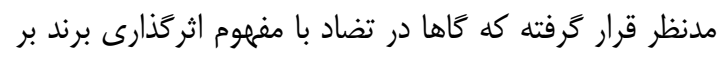

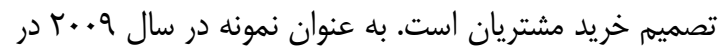

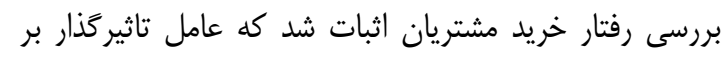

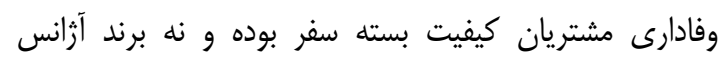

كشورهايى كه مقالات مرتبط با حوزه برند در كردشگَى را

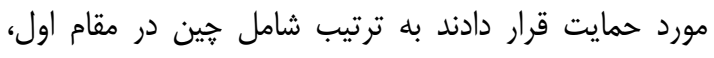

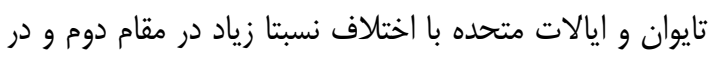

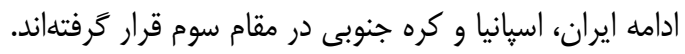

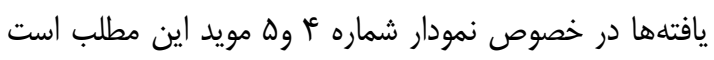

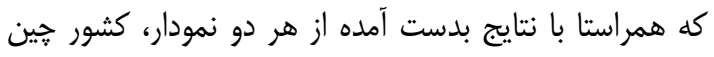

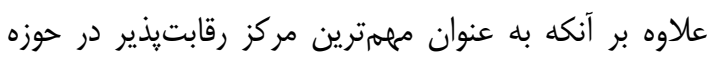

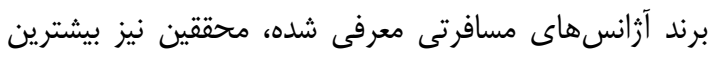

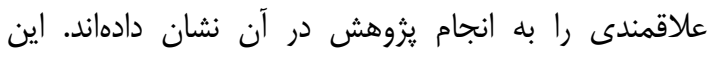

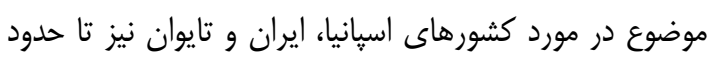

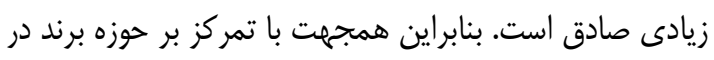

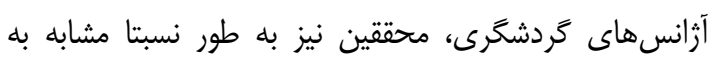

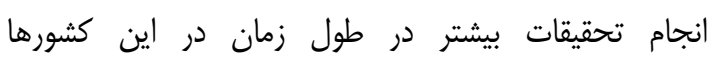
يرداختهاند. از سوى ديخر نتايج در مورد كشورهاى زئر ايالات

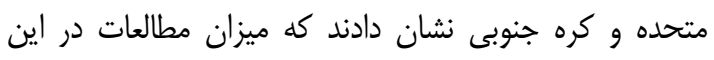

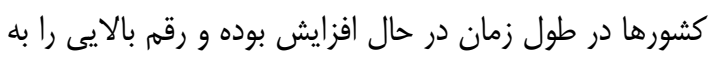

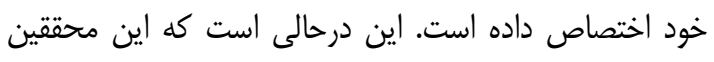

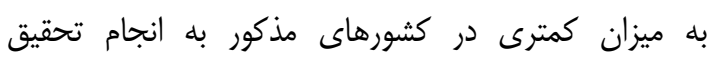

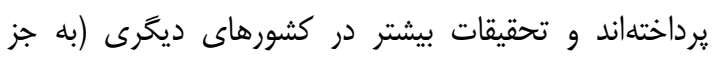

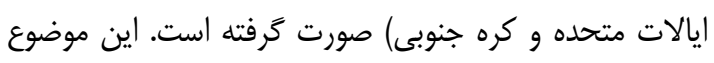

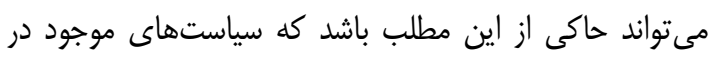

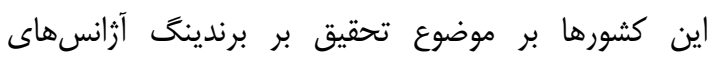

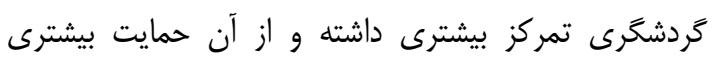

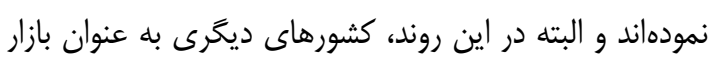
هدف مدنظر قرار كرفتهاند.

\section{تفسير يافتههاى حاصل از مرور مقالات در بازه

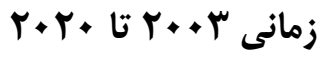

نمودارع شمايى كلى از روند انتشار مطالعات مرتبط با حوزه

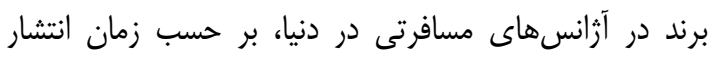

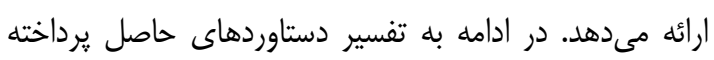
شده است: - اسن

\footnotetext{
${ }^{1}$ Gazzoli et al.
} 
با توجه به سرعت بالاى ييشرفت فناورى در حوزه فناورى

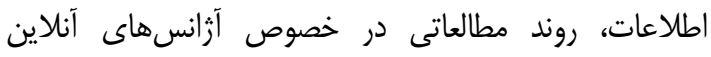

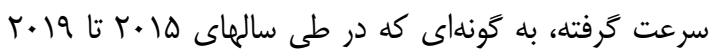

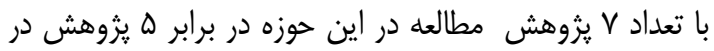

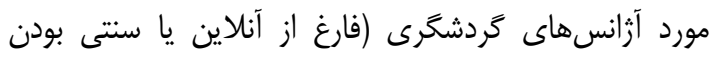

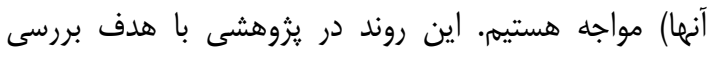
شكاف ديجيتال در توزيع بستههاى سفر در مطالعهاى تركيبى

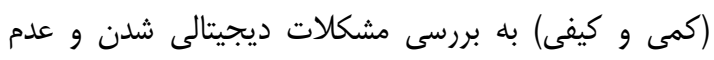

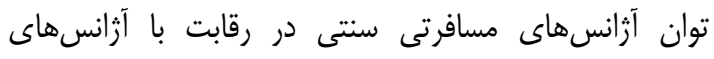
أنلاين مىيردازد. در اين يزوهش محقق ضمن بيان مشكانلات

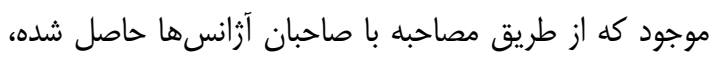

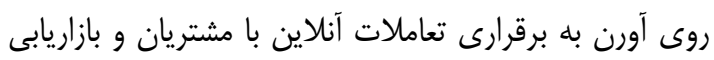
رابطه آنلاين را جايخزينى براى راهكار سنتى تماس مستقيم با باري

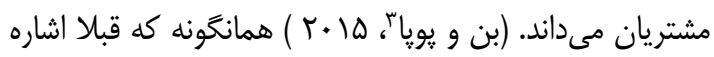

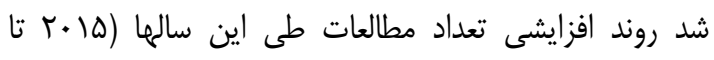

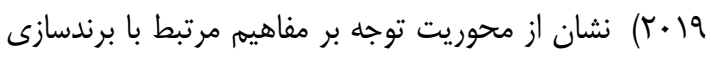

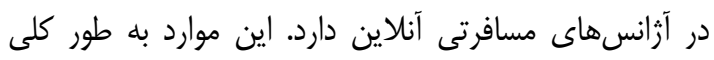

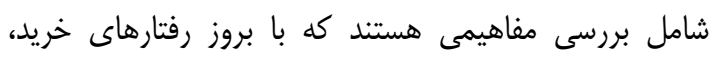

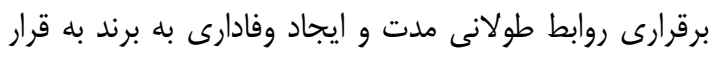
زير در ارتباط اند:

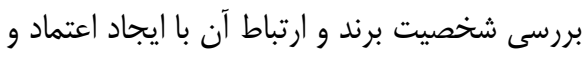

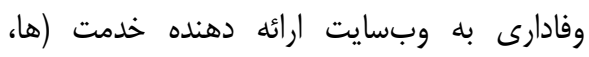

$،(r+19$

بررسى عواملى شامل تاثير ويزگى هاى عملكردى و فنى وب سايت داراى برند بر قصد خريد مشتريان

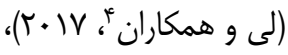
بررسى تعاملات آنلاين اعضاى گروههماى طرفدار

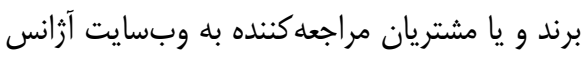

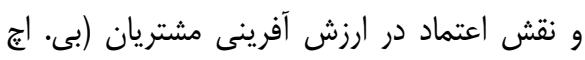

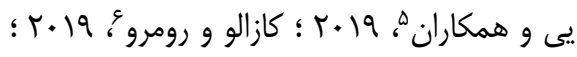
هسو، لr)

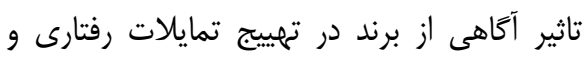

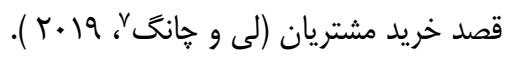
نتايج حاصل از مطالعات انجام شده در اين سالرها، مويد اين

${ }^{3}$ Ban \& Popa

${ }^{4}$ Lee et al.

${ }^{5}$ B. H. Ye et al.

${ }^{6}$ Casaló \& Romero J

${ }^{7}$ Lee \& Chung

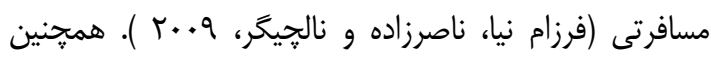

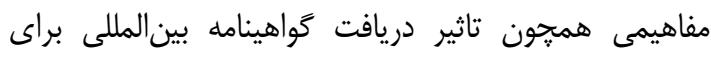
مديريت كيفيت و اطلاعرسانى در اين باره در كنار ارتباطات

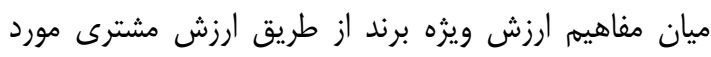

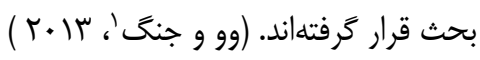

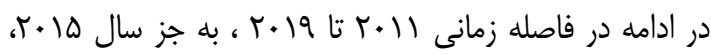
سير مطالعات با يك روند افزايشى مواجه بوده است كه اين موضوع نيز مىتواند نشاندهنده افزايش توجه به موضوع بر برند

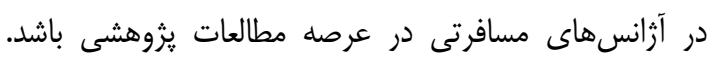

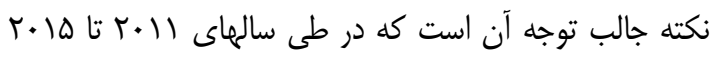

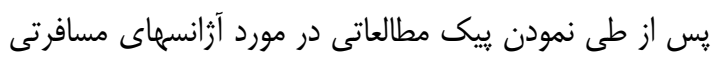

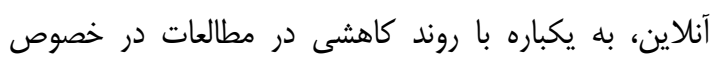

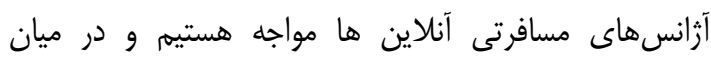
مطالعات موجود در اين دوره تنها يك مورد به بررسى اين نوع

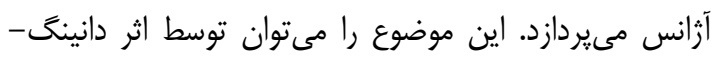

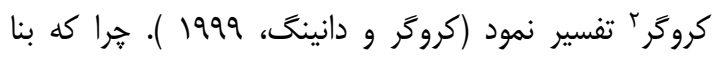

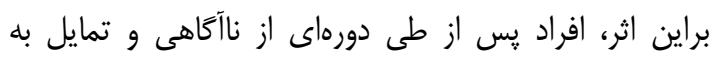

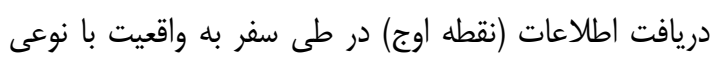

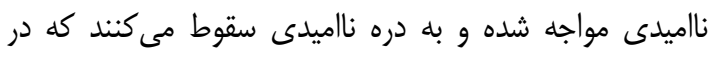

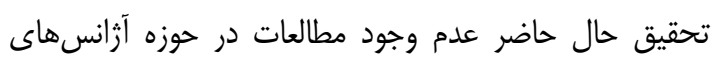

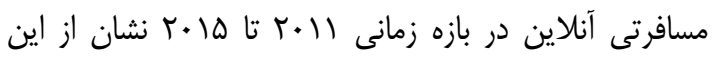

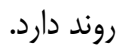

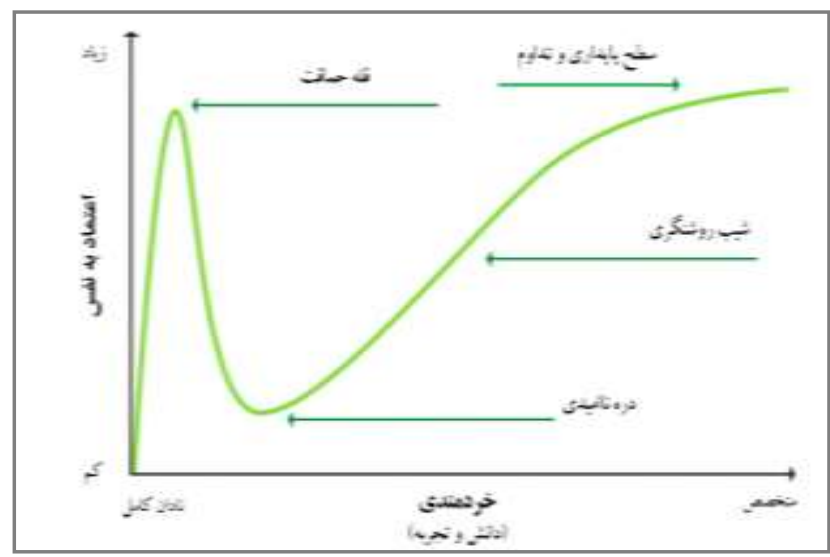

شكل ه. اثر دانينَى- كروكر

منبع: دانينَ- كروگر(1999)

${ }^{1}$ Wu \& Jang

${ }^{2}$ Dunning-Kruger effect 
نقش مسئوليتهاى اجتماعى آزانس در ايجاد

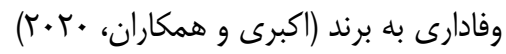

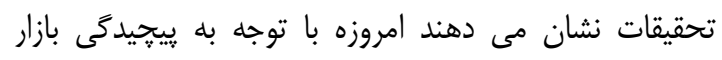
كردشخرى، تنوع خدمات و دشوارى در يِيش بينى اين بازار از

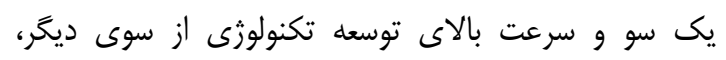

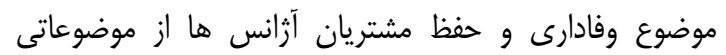
جدى است. در اين راستا، تحقيقات نيز به بررسى تاثيرات

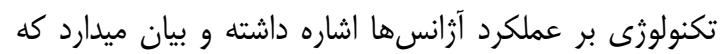

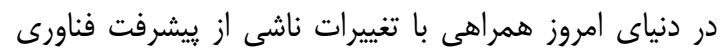

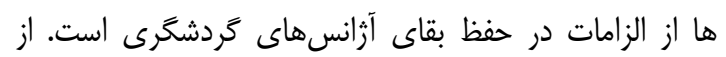

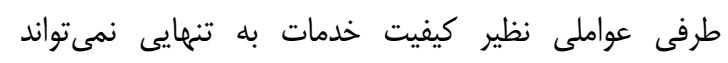

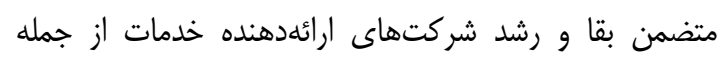

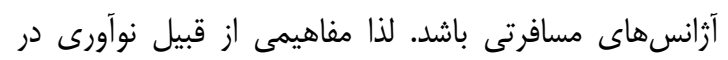

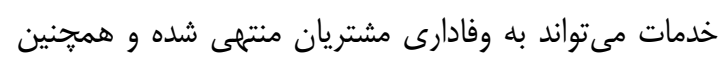

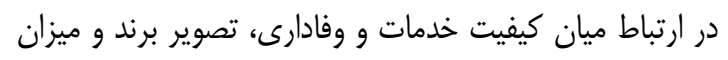
رضايتمندى به عنوان عناصرى واسط عمل مى كنند و اين وفادارى مشتريان است كه منجر به ايجاد بازاريابى دهان به عنديه

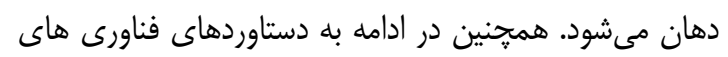

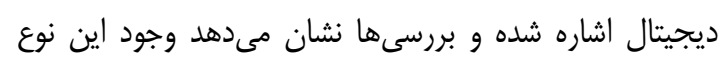

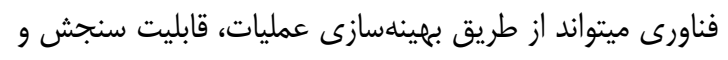
ياسخ گويى مناسب و امكان ارائه خدمات خاص به به مشتريان

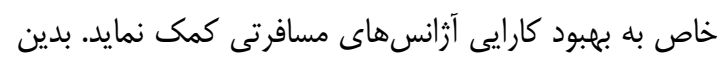

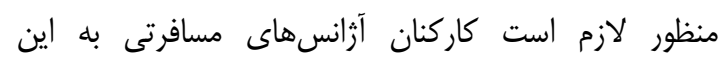

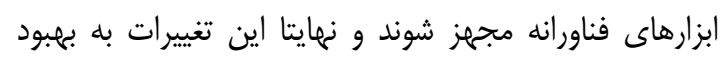

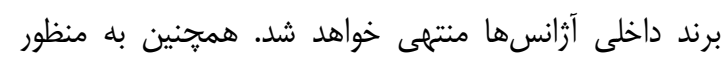

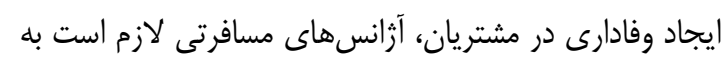

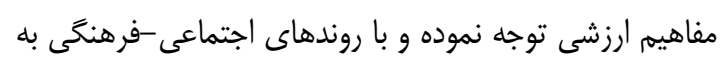
روز در دنيا همراستا شوند. از جمله اين مفاهيم توجه به به رونه اجتماعيه

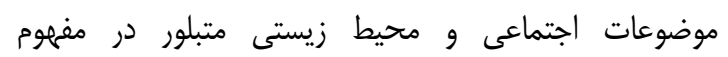

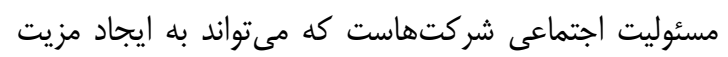
رقابتى در آزانسها منتهى شده و اثنماعي شتركات مهى شود كه اين مفهوم

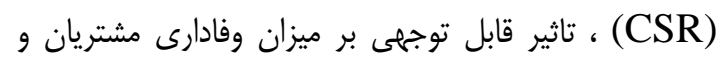

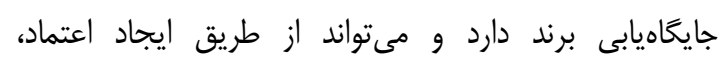

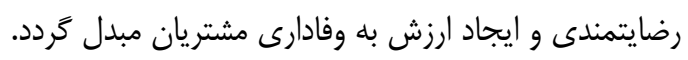

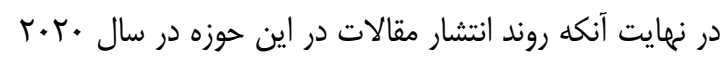

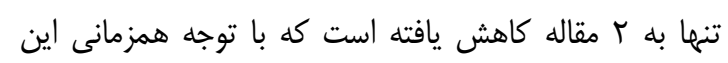

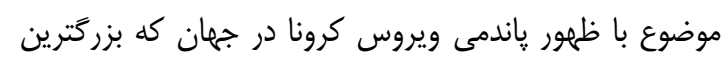
جالش قرن اخير بوده و تاثيراتى همه جانبه بر كليه صنايع و

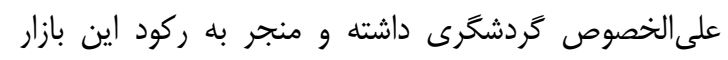
شده و با كاهش ناگمانى تعداد سفرها و از دست رفتن مشاغل
مطلب است كه در آزانسهاى گردشخرى آنلاين اعتماد داراى نقشى اساسى در ارتباط ميان شخصيت برند و وفادارى است و در ادامه با درنظر كرفتن ميزان ادراك مشتريان ازآنجاييكه

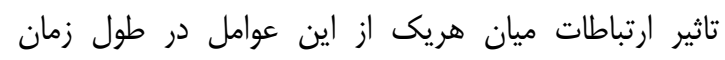
كاهش مى يابد، بنابراين لازم است موضوع اعتماد به نحوه

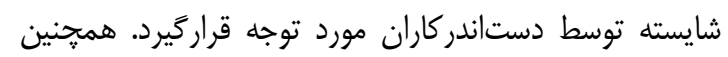

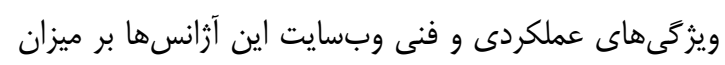

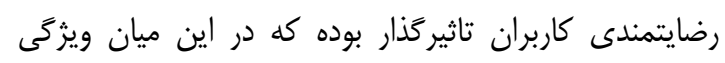
هاى عملكرى كه منجر به ارتقا تجربه سفر مشتريان در بازديد

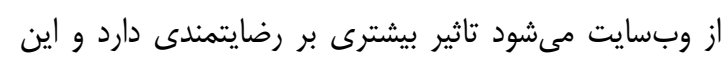

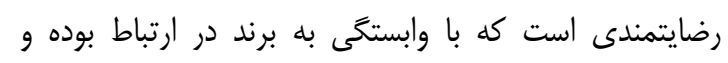

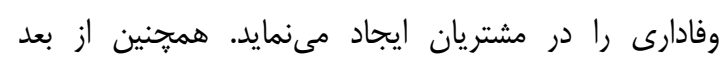
رفتارهاى اجتماعى كاربران در فضاى آنلاين نقش اعتى إيتماد

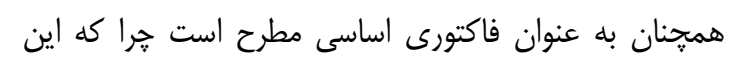

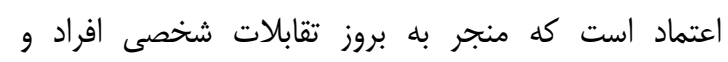

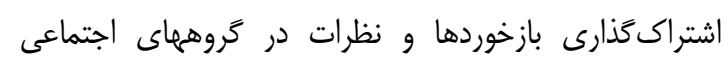

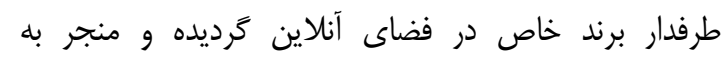

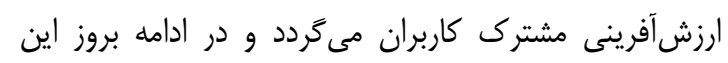

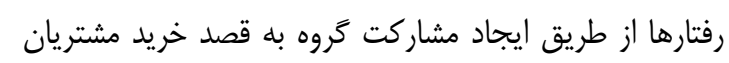

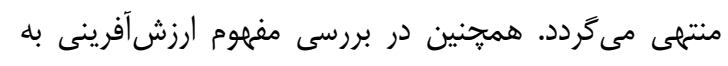

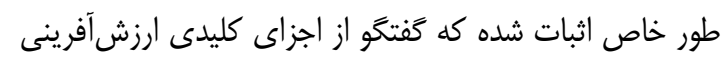

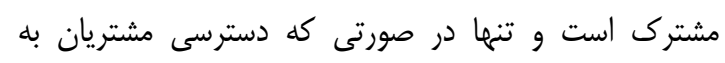
اطلاعات مطلوب و همجنين محتواى ارائه شده در ريلتفرم از كيفيت بالايى برخوردار باشد، اعتماد به برند ايجاد مى مُشود و و

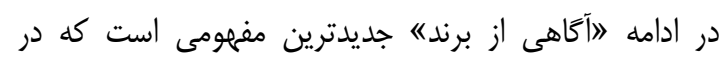

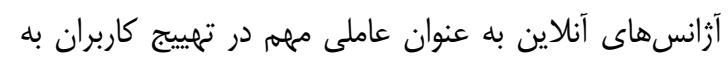

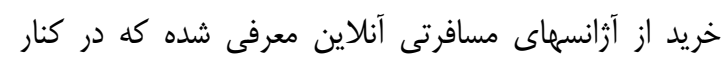

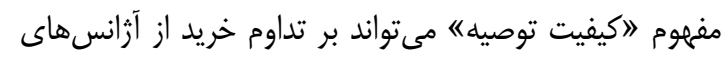
آناين تاثير گذار باشد.

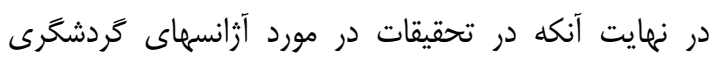

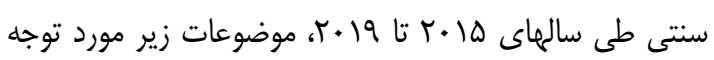
قرار زرفته|ند: تاثير كيفيت خدمات و نوآورى در آن بر رفتارهاى

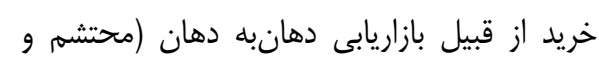

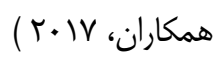

ييوند ميان فناورى و سنتخرايى شامل مهجز

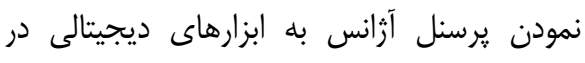

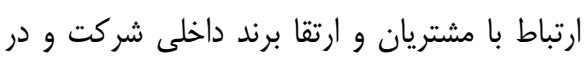

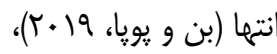


تحويل خدمت خريدارى شده به صورت فيزيكى، تحقيقات در

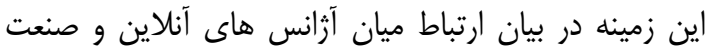

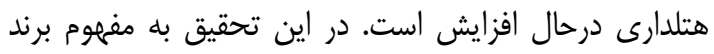

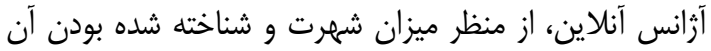

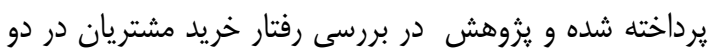
كشور جين و اندونزى نشان داده كه در دردئ ميان متغيرهاى

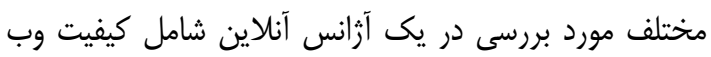
سايت، ميزان شهرت، رضايتمندى از خريد آنايلاين و همجنين إنين

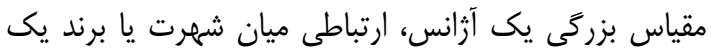

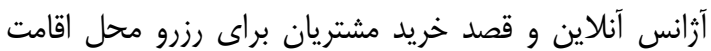
يكى هتل ارتباطى برقرار نيست. اين درحالى است كه بئن بيشترين

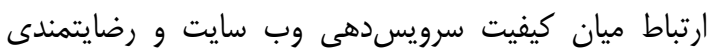

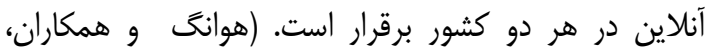

(r.r. بنابراين تحقيقات انجام شده در حوزه برند براى آزرانسهاى

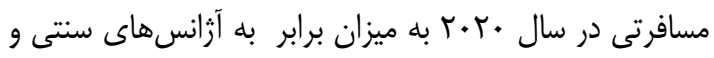

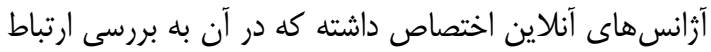

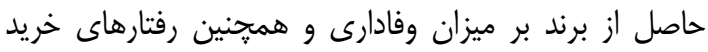

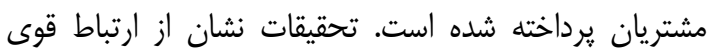

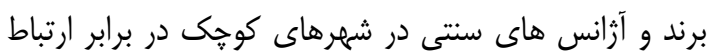

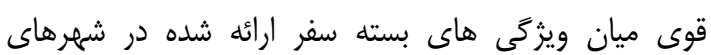
بزرى و همجنين عدم ارتباط ميان برند يك آزانس آنان آناين و

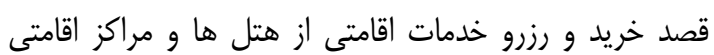
دارد. لذا به نظر مى رسد بنا به تحقيق رديقات انجام شده، مادامى إنى

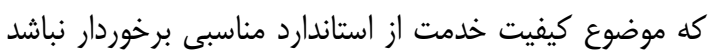

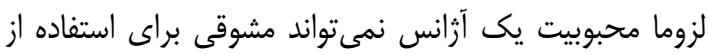

$$
\text { خدمات يك آزانس باشد. }
$$

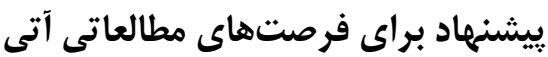

در مطالعه حال حاضردر مرورى نظامند به بررسى روند يزوهشهاى انجام شده در سطح جهان حول موضوع برند و

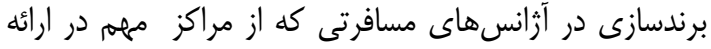

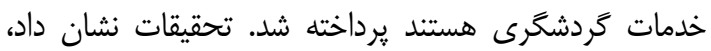
مفهوم برند در آزانس هاى مسافرتى بر خلاف ساير ارائه

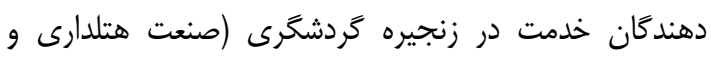

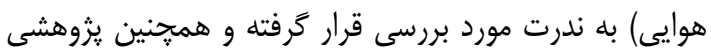
مرورى در اين حوزه وجود ندارد. لذا در اين تحقيق سعى برآن

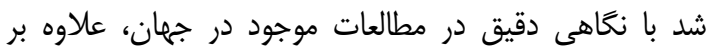
كشف سير مطالعاتى در اين زمينه به شناسايى شكافهاى دان

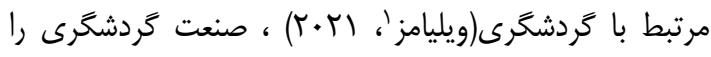

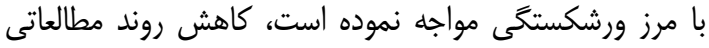

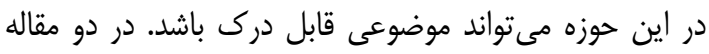

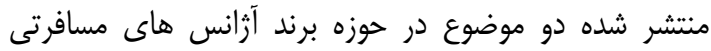
مدنظر قرار كرفته است: تاثير برند آرانس بر انتخاب مشتريان آَّانسهاى

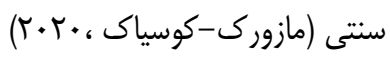

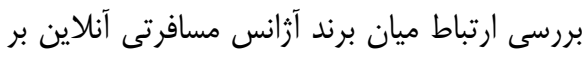

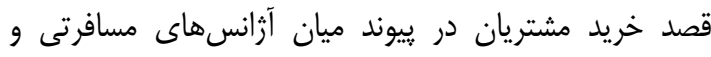
صنعت هتلدارى در تجارت آنلاين به آفلاين بُ (هوانگ،

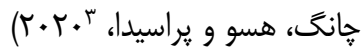
در اين سال مجددا با تاكيد بر لزوم اتخاد استراتزى مناسب در

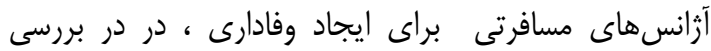

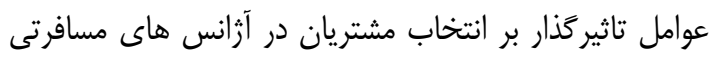
لهرتان بر اساس موقعيت سكونت ساكنين شهرهاى مختلف

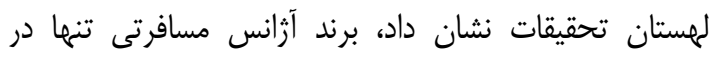

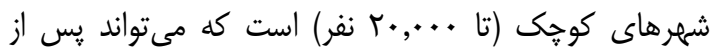

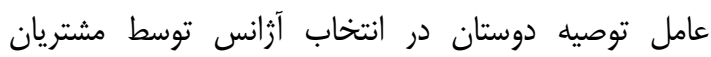
تاثيركذار باشد. اين درحالى است كه در شهرهايى با جمعيت

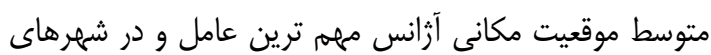

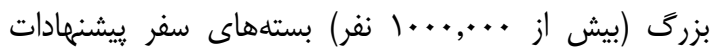
غنى و شخصى سازى شده متناسب با نيازهاى مشتريان است

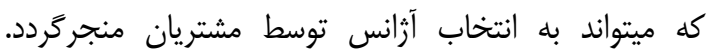

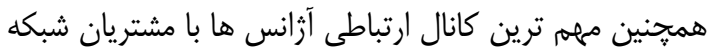

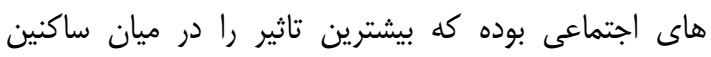

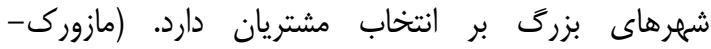

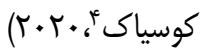
در تحقيق دوم با توجه به افزايش محبوبيت آزانسهاى

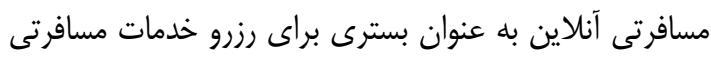
مانند خدمات اقامتى، توجه بيشترى به به رفتارهاى خريد رنايد

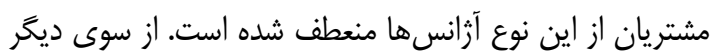

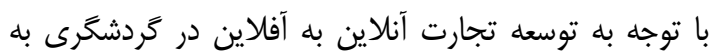

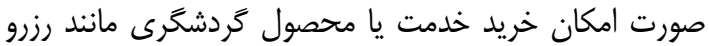

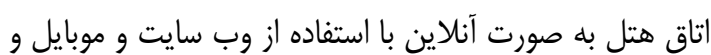

\footnotetext{
${ }^{1}$ Williams

${ }^{2}$ Online to Offline Commerce- (O2O)commerce

${ }^{3}$ Huang, Chang, Hsu, \& Prassida

${ }^{4}$ Mazurek-Kusiak
} 
بنا به مرور ادبيات، بيشترين مطالعات انجام شده در خصوص مفهوم برند در آزانسهاى كردشكَّى به لحاظ

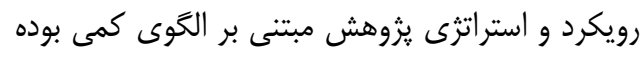

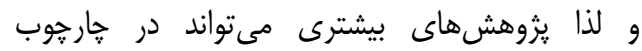
يزوهش كيفى و يا تركيبى در قالب مصاحبه و و يرسشنامه به عنوان ابزارهاى تحقيق انجام شودئ

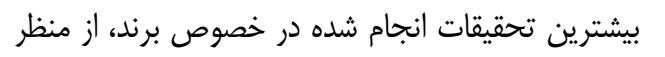

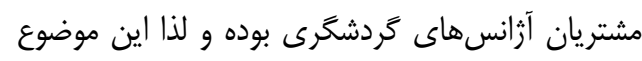

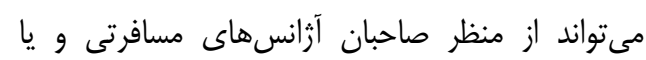

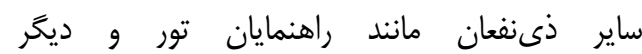

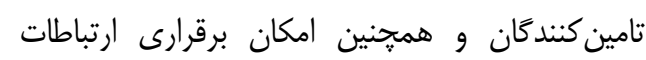

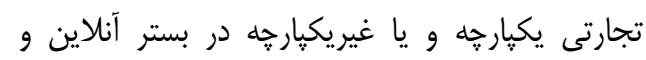
سنتى با رويكرد ايجاد منفعت براى كليه ذيكاريه ذينفعان مورد برد براسى قرار كيرد. با توجه به آنكه اين يُوهش درد در زمان انتشار ياندمى

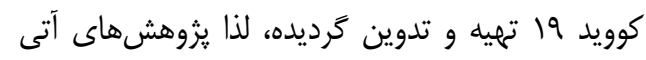
مى تواند ضمن بروزرسانى بازه زمانى تحقيق از زمان تان

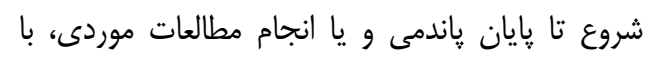

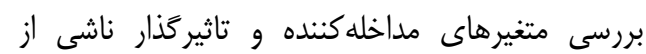

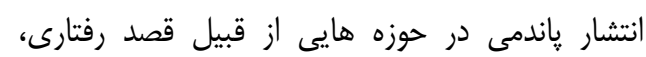

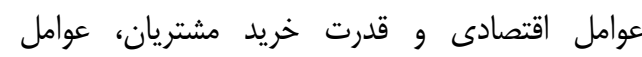

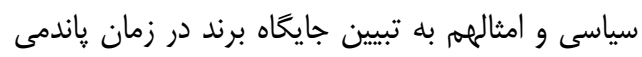

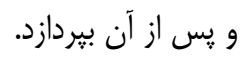

\section{فهرست منابع}

Aaker, D. A. (1992). The value of brand equity. Journal of business strategy.

Aaker, D. A. (1996). Measuring brand equity across products and markets. California management review, $38(3)$.

Akbari, M., Mehrali, M., SeyyedAmiri, N., Rezaei, N., \& Pourjam, A. (2020). Corporate social responsibility, customer loyalty and brand positioning. Social Responsibility Journal.

Arora, R., \& Stoner, C. (1996). The effect of perceived service quality and name familiarity on the service selection decision. Journal of services marketing.

Bailey, R., \& Ball, S. (2006). An exploration of the meanings of hotel
يزوهشى موجود بيردازد تا بتوان از نتايج بدست آمده در توسعه مفهوم برند در كسب و كار آزانسهاى مسافرتى در آينده بهره

\section{برد.}

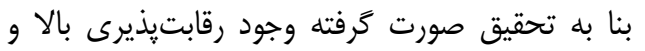

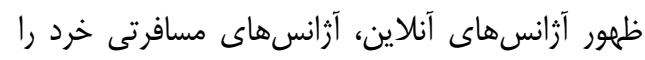

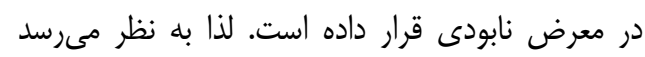

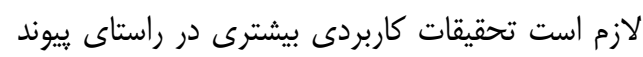

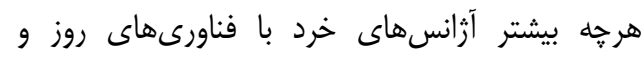

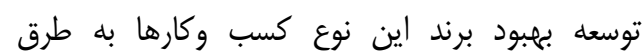
مختلف منجمله مشاركت با آزانس هاى صائ صاحب برندا

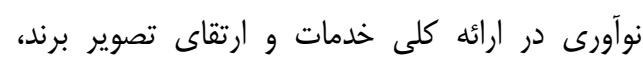

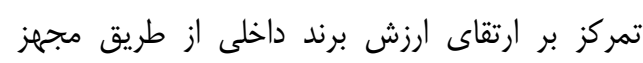

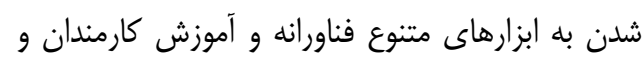

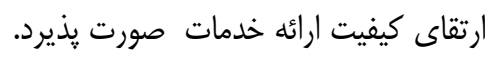
در راستاى توسعه روزافزون ارتباطات اجتماعى در بستر

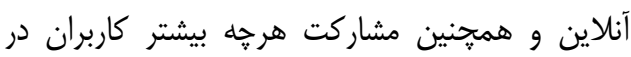

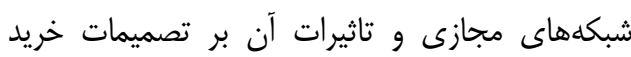

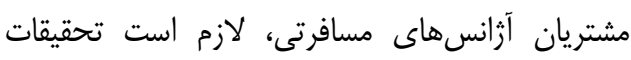

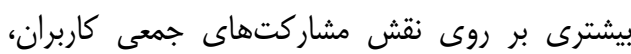

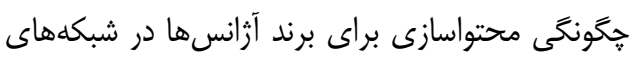

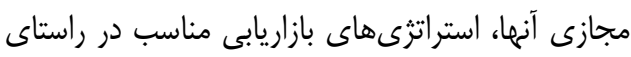

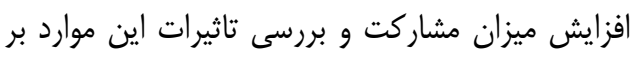

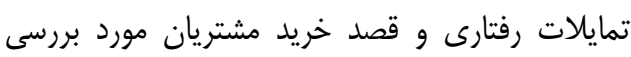

$$
\text { قرار كيرد. }
$$

ازآنجايى كه روند رشد فناورى و ميزان استفاده هرجه بيشتر از بسترهاى آنلاين توسط كاربران براى بلى بران بهره

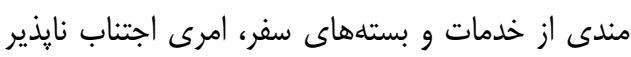
است؛ لازم است، تحقيقات بيشترى بر ارتباطات ميان

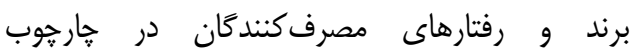
كردشكرى صورت قيذيرد. در اين ميان موضوعاتى از

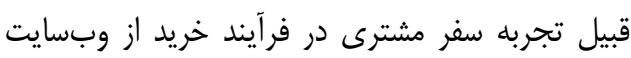

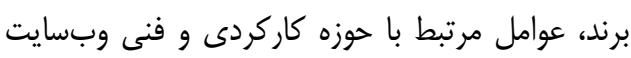

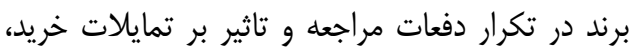

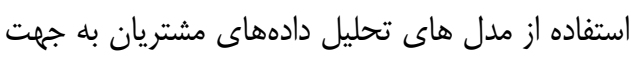
هوشمندى سازى و اختصاصى سازى هرجه بيشتر

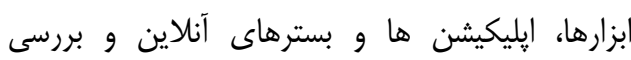

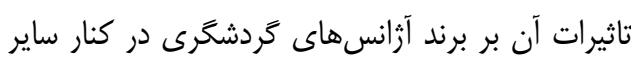

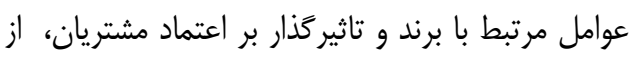

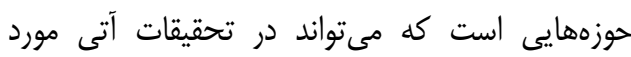

$$
\text { بررسى دقيقتر قرار گيرد. }
$$


Journal of Contemporary Hospitality Management.

Chang, H. H., \& Liu, Y. M. (2009). The impact of brand equity on brand preference and purchase intentions in the service industries. The Service Industries Journal, 29(12), 16871706.

Chang, W. Y., \& Chang, I. Y. (2014). The influences of humorous advertising on brand popularity and advertising effects in the tourism industry. Sustainability, 6(12), 9205-9217.

Chaudhuri, A., \& Holbrook, M. B. (2001). The chain of effects from brand trust and brand affect to brand performance: the role of brand loyalty. Journal of marketing, 65(2), 81-93.

Chen, H., \& Mo, L. (2011). An Empirical Study of the Customer Equity Driving Factors Model of Travel Agency and Its Measurement. Paper presented at the 2011 International Conference on Management and Service Science.

Çifci, S., Ekinci, Y., Whyatt, G., Japutra, A., Molinillo, S., \& Siala, H. (2016). A cross validation of ConsumerBased Brand Equity models: Driving customer equity in retail brands. Journal of Business Research, 69(9), 3740-3747.

Cobb, W., Ruble, C. A., \& Donthu, N. (1995). Brand equity, brand preference, and purchase intent. Journal of advertising, 24(3), 25-40.

Davis, R., Buchanan-Oliver, M., \& Brodie, R. J. (2000). Retail service branding in electronic-commerce environments. Journal of service research, 3(2), 178-186.

Dawar, N., \& Pillutla, M. M. (2000). Impact of product-harm crises on brand equity: The moderating role of consumer expectations. Journal of marketing research, 37(2), 215-226.

Dedeoğlu, B. B., Van Niekerk, M., Weinland, J., \& Celuch, K. (2019). Re-conceptualizing customer-based destination brand equity. Journal of brand equity. The Service Industries Journal, 26(1), 15-38.

Ban, O., \& Popa, A.-L. (2015). Investigating digital divide in travel distribution: The use of Internet and new media technologies in travel agencies of Bihor, Romania. Tourism: An International Interdisciplinary Journal, 63(4), 479496.

Beldona, S., Morrison, A. M., \& O’Leary, J. (2005). Online shopping motivations and pleasure travel products: a correspondence analysis. Tourism Management, 26(4), 561570.

Berry, L. L. (2000). Cultivating service brand equity. Journal of the Academy of marketing Science, 28(1), 128137.

Beverland, M., Lindgreen, A., Napoli, J., Ballantyne, D., \& Aitken, R. (2007). Branding in B2B markets: insights from the service-dominant logic of marketing. Journal of Business \& Industrial Marketing.

Blackston, M. (1992). A brand with an attitude: a suitable case for treatment. Journal of the market research society, 34(3), 231-242.

Blain, C., Levy, S. E., \& Ritchie, J. B. (2005). Destination branding: Insights and practices from destination management organizations. Journal of Travel Research, 43(4), 328-338.

Broyles, S. A., Schumann, D. W., \& Leingpibul, T. (2009). Examining brand equity antecedent/consequence relationships. Journal of Marketing Theory and Practice, 17(2), 145-162.

Buil, I., Martínez, E., \& De Chernatony, L. (2013). The influence of brand equity on consumer responses. Journal of consumer marketing, 30(1), 62-74.

Casaló, L. V., \& Romero, J. (2019). Social media promotions and travelers' value-creating behaviors: the role of perceived support. International 
فصلنامه علمى رهيافتى در مديريت بازر كانى، دوره ז، شماره r، تابستان .. If

Hsu, L.-C. (2017). Investigating community members' purchase intention on Facebook fan page: From a dualistic perspective of trust relationships. Industrial Management \& Data Systems.

Javalgi, R. R. G., Martin, C. L., \& Young, R. B. (2006). Marketing research, market orientation and customer relationship management: a framework and implications for service providers. Journal of services marketing.

Jeng, S.-P. (2016). The influences of airline brand credibility on consumer purchase intentions. Journal of Air Transport Management, 55, 1-8.

Jones, R. (2005). Finding sources of brand value: Developing a stakeholder model of brand equity. Journal of Brand Management, 13(1), 10-32.

Kayaman, R., \& Arasli, H. (2007). Customer based brand equity: evidence from the hotel industry. Managing Service Quality: An International Journal.

Keller, E. (2007). Unleashing the power of word of mouth: Creating brand advocacy to drive growth. Journal of Advertising Research, 47(4), 448452.

Keller, K. L. (2003). Brand synthesis: The multidimensionality of brand knowledge. Journal of consumer research, 29(4), 595-600.

Keller, K. L. (2009). Building strong brands in a modern marketing communications environment. Journal of marketing communications, 15(2-3), 139-155.

Kimpakorn, N., \& Tocquer, G. (2010). Service brand equity and employee brand commitment. Journal of services marketing.

Kruger, J., \& Dunning, D. (1999). Unskilled and unaware of it: how difficulties in recognizing one's own incompetence lead to inflated selfassessments. Journal of personality and social psychology, 77(6), 1121.

Lee, H., \& Chung, N. (2019). Assessing the Factors that Drive Consumers' Intention to Continue Using Online Travel Agencies: A Heuristic- destination marketing \& management, 11, 211-230.

del Blanco, R. M. Á., \& Aaker, D. A. (1995). Estatura de la marca: medir el valor por productos y mercados. Harvard Deusto business review(69), 74-87.

Delgado-Ballester, E., \& HernándezEspallardo, M. (2008a). Building online brands through brand alliances in internet. European Journal of Marketing, 42(9/10), 954-976.

Delgado-Ballester, E., \& HernándezEspallardo, M. (2008b). Effect of brand associations on consumer reactions to unknown on-line brands. International Journal of Electronic Commerce, 12(3), 81-113.

Delgado-Ballester, E., \& Munuera-Alemán, J. L. (2001). Brand trust in the context of consumer loyalty. European Journal of Marketing.

Farzamnia, A., Nasserzadeh, S., \& Nalchigar, S. (2009). Which Internet Marketing Mix's Has More Effect on the Passenger's Decision for Choosing Their Travel Agency in Iran? Paper presented at the 2009 Fifth International Joint Conference on INC, IMS and IDC.

Garbarino, E., \& Johnson, M. S. (1999). The different roles of satisfaction, trust, and commitment in customer relationships. Journal of marketing, 63(2), 70-87.

Gilbert, D., \& Gao, Y. (2005). A failure of UK travel agencies to strengthen zones of tolerance. Tourism and Hospitality Research, 5(4), 306-321.

Ha, H.-Y. (2016). The evolution of brand personality: An application of online travel agencies. Journal of services marketing.

Hoeffler, S., \& Keller, K. L. (2003). The marketing advantages of strong brands. Journal of Brand Management, 10(6), 421-445.

Huang, C.-C., Chang, Y.-W., Hsu, P. Y., \& Prassida, G. F. (2020). A crosscountry investigation of customer transactions from online to offline channels. Industrial Management \& Data Systems. 
Eurasian Business Review, 7(2), 229245.

Moreno Gil, S., \& Celís Sosa, D. F. (2003). Analysis of the travel agencies from the leisure travellers' perception: the Spanish case. Tourism (Zagreb), 51(1), 31-41.

Nam, J., Ekinci, Y., \& Whyatt, G. (2011). Brand equity, brand loyalty and consumer satisfaction. Annals of tourism research, 38(3), 1009-1030.

Rather, A. R. (2018). Exploring customers' attitudes towards the hospitality brands in India: A social identity perspective The branding of tourist destinations: Theoretical and empirical insights: Emerald Publishing Limited.

Sarker, M. M., Mohd-Any, A. A., \& Kamarulzaman, Y. (2019). Conceptualising consumer-based service brand equity (CBSBE) and direct service experience in the airline sector. Journal of hospitality and Tourism Management, 38, 3948.

Saunders, M., Lewis, P., \& Thornhill, A. (2009). Research methods for business students: Pearson education.

Schlesinger Díaz, M. W., \& Cervera Taulet, A. (2008). A comparative study between ideal and perceived brand personality as applied to airline companies: le cas des compagnies aériennes. Innovar, 18(31), 61-76.

Shankar, V., Smith, A. K., \& Rangaswamy, A. (2003). Customer satisfaction and loyalty in online and offline environments. International journal of research in marketing, 20(2), 153-175.

Shen, H., Li, X., \& Zhang, Y. (2018). A Study on Brand Equity of Online Tourism Enterprises Based on User Value Co-Creation Advances in Hospitality and Leisure (pp. 111130): Emerald Publishing Limited.

Srinivasan, V., Park, C. S., \& Chang, D. R. (2005). An approach to the measurement, analysis, and prediction of brand equity and its systematic Model Perspective. Asia Pacific Journal of Information Systems, 29(3), 468-488.

Lee, K.-W., Han, H., \& Hwang, J. (2017). Developing a matrix for assessing serviceability of US online travel agency websites. Social Behavior and Personality: an international journal, 45(1), 115-126.

Li, X., \& Petrick, J. F. (2008). Tourism marketing in an era of paradigm shift. Journal of Travel Research, 46(3), 235-244.

Liu, M. T., Wong, I. A., Shi, G., Chu, R., \& Brock, J. L. (2014). The impact of corporate social responsibility (CSR) performance and perceived brand quality on customer-based brand preference. Journal of services marketing.

Liu, M. T., Wong, I. A., Tseng, T.-H., Chang, A. W.-Y., \& Phau, I. (2017). Applying consumer-based brand equity in luxury hotel branding. Journal of Business Research, 81, 192-202.

Lu, A. C. C., Gursoy, D., \& Lu, C. Y. (2015). Authenticity perceptions, brand equity and brand choice intention: The case of ethnic restaurants. International journal of hospitality management, 50, 36-45.

Madden, T. J., Fehle, F., \& Fournier, S. (2006). Brands matter: An empirical demonstration of the creation of shareholder value through branding. Journal of the Academy of marketing Science, 34(2), 224-235.

Mazurek-Kusiak, A. (2020). Determinants of the selection of travel agencies on polish tourist services market.

McDonald, M. H., De Chernatony, L., \& Harris, F. (2001). Corporate marketing and service brands-Moving beyond the fast-moving consumer goods model. European Journal of Marketing.

Mohtasham, S. S., Sarollahi, S. K., \& Hamirazavi, D. (2017). The effect of service quality and innovation on word of mouth marketing success. 
sources. Management science, 51(9), 1433-1448.

Sun, M., \& Gui, J. (2011). A Study on Travel Agency Brand ManagementBased on the Questionnaire of Beijing Customers. Paper presented at the 2011 International Conference on Management and Service Science.

Tepeci, M. (1999). Increasing brand loyalty in the hospitality industry. International Journal of Contemporary Hospitality Management.

Tranfield, D., Denyer, D., \& Smart, P. (2003). Towards a methodology for developing evidence-informed management knowledge by means of systematic review. British journal of management, 14(3), 207-222.

Villarejo-Ramos, A. F., \& SanchezFranco, M. J. (2005). The impact of marketing communication and price promotion on brand equity. Journal of Brand Management, 12(6), 431444.

Williams, C. C. (2021). Impacts of the coronavirus pandemic on Europe's tourism industry: Addressing tourism enterprises and workers in the undeclared economy. International Journal of Tourism Research, 23(1), 79-88.

Wu, S.-I., \& Jang, J.-Y. (2013). The performance of ISO certification based on consumer perspective: A case study of a travel agency. Total Quality Management \& Business Excellence, 24(3-4), 496-518.

Ye, B. H., Barreda, A. A., Okumus, F., \& Nusair, K. (2017). Website interactivity and brand development of online travel agencies in China: The moderating role of age. Journal of Business Research, 99, 382-389.

Zillifro, T., \& Morais, D. B. (2004). Building customer trust and relationship commitment to a naturebased tourism provider: The role of information investments. Journal of Hospitality \& Leisure Marketing, 11(2-3), 159-172. 